\title{
Kutadgu Bilig'deki Söz Varlığının Günümüz Kırgız Türkçesiyle Karşılaştırılması Üzerine
}

\author{
Ceyhun Vedat UYGUR ${ }^{1}$
}

\section{$\ddot{O} z$}

$\mathrm{Bu}$ çalışma, on birinci yüzyılın Doğu (Karahanlı) Türkçesiyle yazılmış en önemli ve hacimli manzum eseri olan Kutadgu Bilig’in kelime kadrosunu, günümüz Türk lehçelerinden Kırgız Türkçesiyle karşılaştırmaktadır. Çalışma, 'Türkiye'de Reşit Rahmeti Arat tarafindan hazırlanıp yayımlanan Kutadgu Bilig Metin ve Tercüme'leri ile (Yusuf Has Hacib Kutadgu Bilig I-Metin, Yusuf Has Hacib Kutadgu Bilig II-Tercüme) yine onun tarafindan hazırlanan ancak K. Eraslan, O.F. Sertkaya, N. Yüce tarafından neşre hazırlanıp yayımlanan Kutadgu Bilig III İndeks'e dayanmaktadır. İndeks'teki her kelime ve anlamı Kırgız Türkçesindeki şekil ve anlamlarıyla karşılaştırılmış; Kutadgu Bilig'deki her bir açıklayıcı anlamın Kırgız Türkçesindeki karşılığı verilmeye çalışılmış; değişen anlamlar, değişen (farkli) yapılar, eskiyen kelimeler tespit edilmiştir. İndeks’te olması gereken ve Semih Tezcan'ın önerdiği kelimeler de (eğer Kırgizca karşllı̆̆ varsa) çalışmaya dâhil edilmiştir. Anlam veya okunuşunda sorunlu bulunan İndeks’teki kelimeler (113 adet) çalışmaya alınmamıştır. Sonuçta, yaklaşık üç bine yakın (2998) kelimeyi barındıran Kutadgu Bilig'deki kelimelerin yaklaşık olarak \% 46/47 oranında Kırgız Türkçesinde kısmen anlam ve yapı değişmesine uğrayarak ama en fazla da ses değişmelerine ve olaylarına maruz kalarak yaşadığı tespit edilmiştir.

Anahtar Kelimeler: Kutadgu Bilig, Söz Varlı̆ğ, Kırgız Türkçesi, Kutadgu Bilig ve Kırgızca, Karşılaştırma

\section{On Comparison of Vocabulary in "Kutadgu Bilig" with Contemporary Kyrgyz Language}

\section{Abstract}

The present study aims to compare the vocabulary of Kutadgu Bilig with the Kyrgyz language of contemporary Turkish dialect, which is the most important and voluminous didactic poem written in Eastern (Karahanids) Turkish of the eleventh century. This study is based on the copies and translations of Kutadgu Bilig published by Reshit Rahmet Arat (Yusuf Has Hajib Kutadgu Bilig I -Metin (Copy), Yusuf Has Hajib Kutadgu Bilig II -Tercume (Translation) and Kutadgu Bilig III which was also prepared by him, but published by K. Eraslan, O.F. Sertkaya, N. Yuje. Each word and its meaning in Index is compared with its forms and meaning in Kyrgyz; every descriptive meaning in Kutadgu Bilig is attempted to be given in Kyrgyz; changes in the meaning, changes in the structure, obsolete words are identified. Words that should take place in Index and proposed by Semih Tezcan (if there is Kyrgyz equivalent) are also included. Words (113) that are considered problematic in Index in terms of meaning and reading are not included in this study. As a result of this study, it is identified that approximately $46 / 47 \%$ of words from Kutadgu Bilig, which has nearly three thousand words (2998) exist in Kyrgyz language by changing the meaning and sturcture, but mostly by being exposed to sound change.

Key Words: Kutadgu Bilig, Vocabulary, the Kyrgyz language, Kutadgu Bilig and Kyrgyz, Comparison

\section{Atıf İçin / Please Cite As:}

Uygur, C. V. (2020). Kutadgu Bilig’deki söz varlı̆ı̆nın günümüz kırgız türkçesiyle karşılaştırılması üzerine. Manas Sosyal Arasttrmalar Dergisi, 9(3), 1300-1330.

Geliş Tarihi / Received Date: 18.03.2020

Kabul Tarihi / Accepted Date: 22.05.2020

\footnotetext{
1 Prof. Dr. - 1. Kırgızistan-Türkiye Manas Üniversitesi Edebiyat Fakültesi 2. Pamukkale Üniversitesi Fen-Edebiyat Fakültesi Türk Dili ve Edebiyat1 Bölümü, ceyhunv.uygur@manas.edu.kg, vuygur@hotmail.com, ORCID: 0000-0003-4239-803X
} 


\section{Giriş}

Bugüne kadar Kutadgu Bilig üzerine pek çok araştırma yapılmıştır. Buna rağmen hâlâ onun tam olarak incelenmeyen tarafları bulunmaktadır. Bunların en önemlilerinden biri, belki ondaki söz varlığının günümüz Türk lehçelerinde ne ölçüde ve hangi biçimlerde yaşayıp yaşamadığıdır. Başka bir deyişle 11. yy. Doğu Türkçesi edebî diliyle yazılmış olan bu dev eserin kelime hazinesinin bugünkü Türk lehçeleriyle bir karşılaştırmasının yapılmamıs olmasıdır. Bu konuda kısmi çalışmalar bulunsa da (mesela Anadolu ağızlarılya karşılaştırma gibi) biz, bu çalışmamızda Kutadgu Bilig’in bütün bir söz varllğını çağdaş Türk lehçelerinden Kırgız Türkçesiyle karşılaştırmaya çalıştık. Çalışmamız, R. Rahmeti ARAT tarafindan hazırlanan ve K. Eraslan, O. F. Sertkaya, N. Yüce tarafindan yayımlanan (1979) Kutadgu Bilig III-İndeks adlı çalışmaya dayanmaktadır. İndeks’in sıhhati tartışılsa da, konuyla ilgili mevcut görüş ve yayınlar da çalısmamızda dikkate alınmıştır. Sorunlu kelimeleri ciddi bir şekilde tartışan bilim adamı Semih Tezcan olmuştur (Tezcan, 1981). Bu sebeple onun fikirleri, çalışmamızda (Kırgız Türkçesinde bir karşıllı̆ı varsa) dikkate alınmış, görüşleri ilgili kelimede parantez içinde verilmiş, bu husus da */s ("sorunlu" anlamında) şeklinde işaretlenmiştir. Yine bu bağlamda, İndeks'te yer almayan ama Tezcan'in "olmasi/ eklenmesi gerekir" dediği kelimeler de eğer Kırgız Türkçesinde karşılı̆̆ varsa çalışmamıza dâhil edilmiş ve */i (ilave) ile işaretlenmiştir.

Kutadgu Bilig'de üç bine yakın kelime bulunmaktadır. Çalışmamızda bu kelimelerin tamamı (içlerine okunuş ve anlam açısından sorunlu, tartışmalı olanlar da var) günümüz Kırgız Türkçesiyle karşılaştırılmış; her bir kelimenin anlamı / anlamları, anlam değişmeleri, ses değişmeleri, yapısı karşılaştırma kapsamına alınmıştır.

Çalışmamızın bir özelliği de Kutadgu Bilig İndeks’inde yer alan kelimelerin anlamlarını ortaya koyan her kelimenin olabildiğince Kırgız Türkçesinde karşılığının / karşılıklarının verilmeye çalışılmasıdır. Örneğin Kutadgu Bilig'deki (KB) ag̀rı̇ kelimesi, İndeks'te ağrn, zabmet, hastalık şeklinde anlamlandırılmış. Söz konusu anlamı veren üç kelimenin de Kırgız Türkçesindeki karşılıkları bulunup yazılmaya çalışılmışır. Kelime anlamları yatık (italik) harflerle verilmiştir:

KB ag̀ng Ağrl; $\quad$ Krg. ooru; z̧abmet Krg. kıyınçllık; hastalı. Krg. ooru gibi.

Bütün kelimeler yukarıda gösterildiği şekliyle çalışmaya alınmıştır. Kırgız Türkçesinde karşllğını yazamadığımız kelimelerin yeri boş bırakılmıştır.

Kutadgu Bilig'deki özel isimler, (birkaç istisna dışında) çalışmamıza dâhil edilmemiştir.

Tespitlerimize göre Kutadgu Bilig'deki kelimelerin 1543 adedi, bugünkü Kırgız Türkçesinde yaşamaya devam etmektedir. 1543 adet kelimenin bir kısmı anlam bakımından, bir kısmı ses bakımından, bir kısmı da yap1 bakımından değişikliğe uğramıştır. Bu durum doğal kabul edilmelidir. Çünkü bugünkü Kırgız Türkçesi, Sovyetler Birliği döneminde yazı dili hâline getirilmiştir. Yani o zamana kadar Kırgız Türkçesi, sözlü bir diyalekt durumundaydı. Diyalektler, ağızlar, elbette ki edebî dile göre özellikle ses bakımından değişiklik gösterecektir. Başka bir deyişle Kutadgu Bilig metnindeki kelimelerin ses (telaffuz) bakımından değişiklik göstermesinin temel sebebi, bir anlamda metnin Kırgız Türkçesinin seslik, sesletim değerlerine uygun duruma getirilmesidir. Bu durum, Kazak, Karakalpak, Nogay, Tatar gibi diğer Türk diyalektleri için de geçerlidir.

Türkiye Türkçesinde fiillerin mastar biçimlerini biz genellikle $-m A k$ eki ile karşıllyoruz. Soyut fiilleri de -mAk okutan "fiil çizgisi" ile (-) karşllyoruz. Kırgız Türkçesinde bu durum, kök veya gövdedeki ünlünün durumuna göre -uu, -üü, -oo, -öö $(<-1 \dot{g}$, -ig) biçimine girmektedir. Biz de çalışmamızda fillleri bu şekilde gösterdik. Böylece fiilleri, isim-fiil biçimlerinden ayırmış olduk.

Çalışmamızda bazı işaretler kullandık. Bunlar ve karşıladıkları anlamlar şöyledir:

*/m: KB'den bu yana Kırgız Türkçesinde manası değissen kelimeler,

*/k: KB’den bu yana Kırgız Türkçesinde yapısı kısmen değişen kelimeler,

*/e: KB'de olup da Kırgız Türkçesinde eskimiş olan kelimeler,

*/h: KB'de olup da bugün Kırgız Türkçesinde halk ağzında yaşayan kelimeler,

*/v: KB'de birbirinin varyant1 durumunda olan kelimeler, 
*/i: İndeks'te olmayan ve Tezcan'ın önerisiyle ilave edilmiş olan kelimeler.

*/öi: özel isim

\section{Değişmeden Günümüz Kırg1z Türkçesine Ulaşan Kelimeler}

Bunlar içinde az da olsa anlam değişmesine veya kısmen yapısal değişikliğe uğrayanları görmek mümkündür (Bunları $* / \mathrm{m}$ veya $* / \mathrm{k}$ işaretleriyle belirttik). Bazı kelimeler de Kutadgu Bilig İndeksinde varyantlı olarak yer almıştır. Bunları da */v işaretiyle gösterdik. Ama aşağıdaki örneklerin büyük bir kısmında kelimeler, anlam ve yapı bakımından değişmeden günümüz Kırgız Türkçesinde kullanılmaktadır:

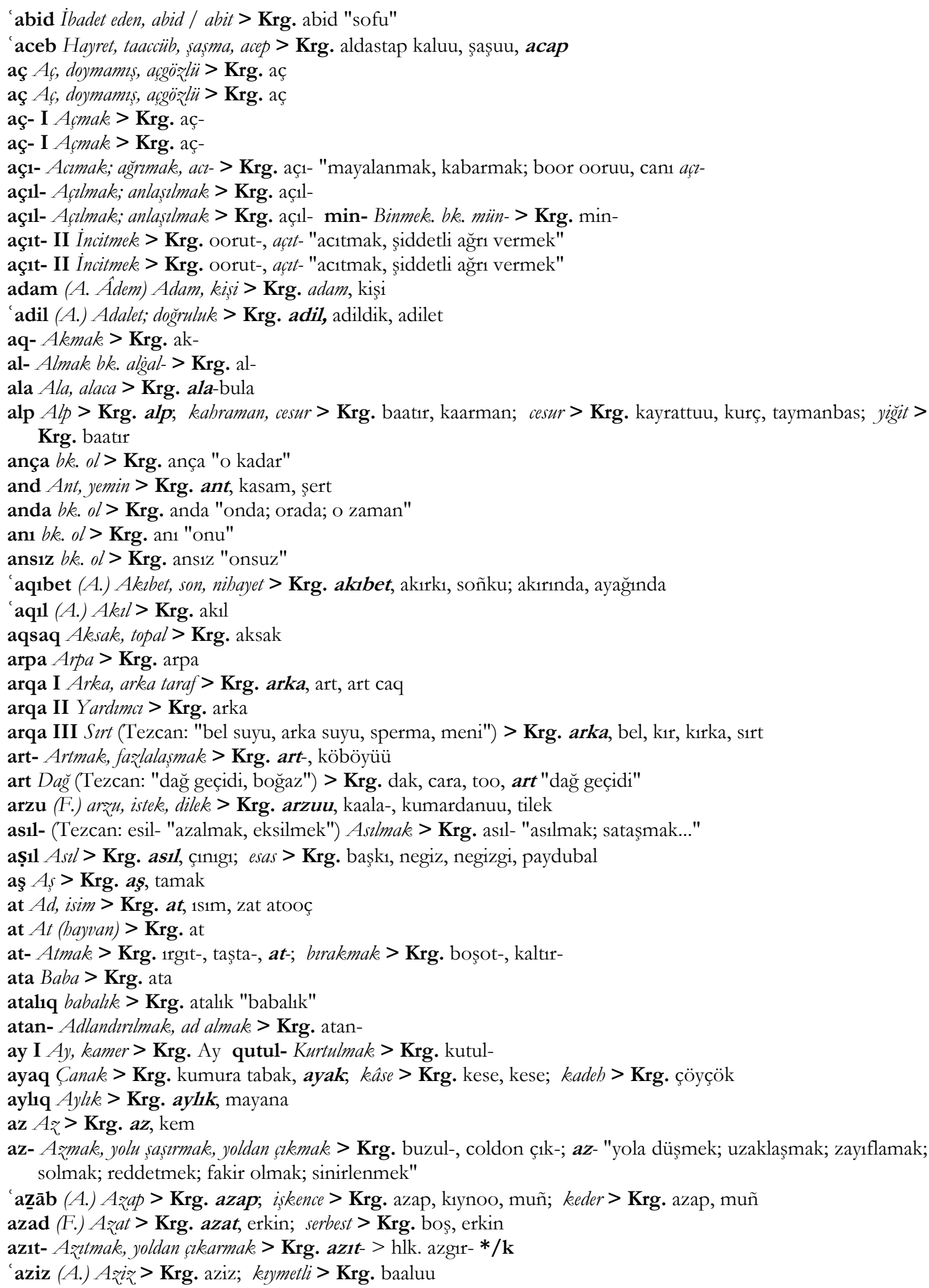


balıq Ballk > Krg. balık

baq- Bakmak > Krg. bak-, kara-, tikte-

bar $V$ ar $>$ Krg. bar; mevcut $>$ Krg. bar, bar bolgon

bar- Varmak $>$ Krg. cet-, kel-, bar-; gitmek $>$ Krg. ket-

barı Bütünü, tamamı, hepsi > Krg. baarı, bardı1, calpıs1

bas- Basmak > Krg. basıp çıgar-, bas-, ter-

basıl- Basılmak > Krg. basil-

baş Baș > Krg. baş; ön > Krg. aldı, öñ; $u c ̧>$ Krg. uç

başçı Başkean; şef > Krg. başçı, başkarma, töraga; baş > Krg. baş

bat- Batmak > Krg. bat-; sinmek > Krg. basin-; gözden kaybolmak; saklanmak, gizlenmek

bata (Tezcan: Bu kelime çıarılmalı ve bat ile birleștirilmeli) Derhal > Krg. daroo, tez; cabuk. bk. bat $>$ Krg. çapçañ, çırak, tez */s

bay Zengin $>$ Krg. bay

baylıq Zenginlik > Krg. baylik

bedel (A.) Bedel > Krg. bedel "bedel, değer"; karşıllk > Krg. 1layık kelüü, coop, tuura kelüü

bek Sağlam, mubkem > Krg. çıñ, deni sak, bek "sert, katı, dayanıklı; sağlam; kilitli, apalı; pek, çok; sağlam, güvenilir"

beki- Sağlamlașmak > Krg. beki-

bekit- Pekitmek, sağlamlastırmak. bk. bekit-, beküt- > Krg. bekit-

berk Sağlam, kuvvetli > Krg. çıñ, deni sak, berk"sağlam, berk", bek

beter (F.) Daha kötü, daha fena > Krg. beter

beyt I (A.) Beyit, ev > Krg. beyt

beyt II (A.) Ev > Krg. üy, beyit

beze- Bezemek > Krg. casalgala-, koozdo-, körkömdö-, bez̨e-; süslemek > Krg. casan-

bezen- Bezenmek, süslenmek > Krg. bezen-, bezel-

bıç- Biçmek, kesmek. bk. biç- > Krg. biç-, or-

biçaq Bıçak. bk. biçek > Krg. biçak

b1ş- Pişmek > Krg. bıss-; olgunlaşmak > Krg.

b1şur- Pişirmek $>$ Krg. bişır-

biç- Bicmek > Krg. biç-, oruu ; kesmek. bk. bıç- > Krg. kes-, toktot-

bil- Bilmek > Krg. bil-

bilek Bilek $>$ Krg. bilek

bilin- Bilmek, anlamak > Krg. bilin- "bilinmek", bil-, anda-, tüşün- */m

biliş- Bilişmek, tamışmak > Krg. biliş- "tanınmış olmak, aşikâr olmak" */m

bir Bir > Krg. bir

birik- Birikmek > Krg. birik-, c1yıl-, koşul-; toplanmak, bir olmak > Krg.

biriktür- Biriktirmek (Tezcan: "birleştirmek, birbirine uygun duruma getirmek) $>$ Krg. biriktir-

birlik Birlik, vahdet > Krg. birdik, birlik

biz Biz > Krg. biz

bol- Olmak > Krg. bolup kal-, bol-

boş Boş > Krg. boş; serbest > Krg. boş, erkin

boz Boz renk $>$ Krg. boz

börk Külah, başlık, kalpak > Krg. külö, şökülö, börk

böz Bez (pamuktan yapılmus kumass) > Krg. bez "beze, gudde", böz, kezdeme

bu $B u>$ Krg. $\boldsymbol{b u}$, bul, oșol

bulaq Pinar $>$ Krg. kaynar, bulak

bulg̀aş- Karışmak > Krg. aralaş-, çataş-, kiyligiş-, bulğaş-

bulun- Bulunmak > Krg. bol-, bulun- "bulunmak" sol Sol > Krg. sol

buqa Boğa > Krg. buka

bur- Burmak, sikilaştırmak > Krg. bur-, kayra-, tolga-

burhan Burkan, put $>$ Krg. burhan

but But, bacak > Krg. san; bacak > Krg. but sök-Sörmek > Krg. sök-, uruş-

but Put $>$ Krg. but

buyur- Buyurmak, emretmek > Krg. buyruk ber-, buyur-, carlık k1l-

buz- Bozmak > Krg. buz-; yıkmak > Krg. c1k-; harap etmek > Krg. eskirt-, kiyrat-, tozdur-; viraneye çevirmek, darmadağm etmek $>\mathbf{K r g}$.

buzul- Bozulmak > Krg. buzul-; yıkılmak > Krg. cig1l-

buzuq Bozuk > Krg. buzuk; kirnk, yıkık > Krg. kiyragan, singan, sinik

bütün Bütün > Krg. baar1, bütkül, bütün

bütür- Sağaltmak, sağlam hâle koymak > Krg. bütür- "bitirmek, tüketmek; mezun olmak" */m

can (F.) Can > Krg. can; ruh > Krg. rux, şaytan; gönül > Krg. könül; yürek > Krg. cürök; kalp > Krg. cürök; kuvvet $>$ Krg. kubat, küç; kudret $>$ Krg. kubat, kuduret, küç 
çal Alaca > Krg. ala-bula, ak-sarı, boz, çal "kır renk"

çal- Yere çalmak, vurmak > Krg. at-, ur-, çal-

çıq- Cıkmak > Krg. çık-

çıqar- Çıkarmak > Krg. çıgar-

çök- Cökmek > Krg. çök-

$\operatorname{din}($ A.) Din $>$ Krg. din

duşman (F.) Düşman > Krg. duşman, coo

eger (F.) Ë̆еr $>$ Krg. eger, egerde

ek- Bir sey ekmek > Krg. ek-

em İlac > Krg. darı, em "ilaç, şifa; aşı"

emçi Tabip > Krg. tabıp, emçi "üfürükçü" */m

emgek Emek > Krg. emgek, meenet; zabmet > Krg. kı1nçıllik; ęijyet > Krg. kısım casa-, kıs-

emma (A.) Ama, ancak, şu kadar ki, kaldı ki > Krg. birok, uşul gana, amma "ama; bütünü, hepsi" (halk ağzi)

eñ En > Krg. eñ; daha (kuvvetlendirme edatr) > Krg. dag1, eñ

er Er, erkek, adam > Krg. asker, er, erkek, kaarman, kayrattuu

erdem Erdem, farilet > Krg. coomarttık, tatıktuuluk; erdem "yiğit, er, kahraman" */m

eren Insan, insanlar > Krg. adam, kişi, eren "er, yiğit"

erk Kudret, güç > Krg. kubat, kuduret, küç, erk

erkeç Genç teke > Krg. erkeç

erkek Erkek > Krg. erkek

erte Erte, erken $>$ Krg. erte

es- Esmek > Krg. cel cür-, şamal bol-, es- "esmek, üfürmek; çırpınmak"

1nan- Inanmak > Krg. Inan-, işen-

1nanç Güvenilen, inanılan; güvenme, inanma > Krg. ınanıç "inanç"; ınanış "inanış"

1sin- (Tezcan: isin-) Isinmak > Krg. c1lin-, 1sin-

$\mathbf{1 s ̧}$ Sis $>$ Krg. tuman, 1 ş "is"

iç $\dot{I}_{c}>$ Krg. iç, içki cak

iç- İcmek > Krg. çek-, iç-, tart-

il- I Bağlamak, iliştirmek > Krg. bayla-, bekit-, il- "asmak, bağlamak, iliştirmek, takmak..."

'ilim (A.) Ilim, bilme, bilis > Krg. ilim

ilin- Yakalanmak, tutulmak > Krg. ilin- "tutulmak, yakalanmak, takilmak"

iliş- Birbirine ilișmek, çatışmak $>$ Krg. iliş-, çatış-, uruş- akıllı $>\mathbf{K r g}$. akılduu */m

ini (yaşsa) Kücük kardeş > Krg. ini

iş $\dot{I}_{s}>\mathrm{Krg}$. biznes, $\boldsymbol{i s ̧}$, cumuş

işçi $\dot{I}_{s ̧ ̧} i>$ Krg. cumuşçu, işçi

işen- Güvenmek $>$ Krg. işen-, süyön-; inanmak $>$ Krg. inan-, işen-

it Köpek, bk. it > Krg. it

iz $\dot{I}_{z}>$ Krg. iz; nişan > Krg. belgi

qaçan $\mathrm{Ne}$ zaman, ne vakit $>$ Krg. kaçan

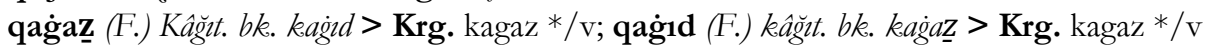

qal- Kalmak $>$ Krg. kal-

qalem (A.) Kalem > Krg. kalem, karandaş

qalın Kalabalık > Krg. kalıñ top, qalıñ el; çok > Krg. köp, ötö, abdan, kalıñ

qalqan Kalkan > Krg. kalkan, kambala toñ Sert, katı > Krg. katuu, toñ "don, buz tutma; ham, olmamış; soğuk, ilgisiz" */m

qamçı Kamçı > Krg. kamçı

qan Kan > Krg. kan

qanat Kanat $>$ Krg. kanat

qana'at (A.) Kanaat > Krg. kanaat, kanaatangandık

qap qara Kapkara > Krg. kapkara

qap- Tutmak > Krg. cakala-, karma-, sakta-, tut-, kap- "köpek 1sırmak; ağır konuşmak, sözle saldırmak" */m qar Kar $>$ Krg. kar

qara I Kara (Tezcan: 2715 'te doğrudan doğruya 'mürekkep' anlamında kullanılmıştır.) > Krg. caman, kara, kurgak

qarar (A.) Karar > Krg. çeçim, toktom, karar "karar, yargı" (eski) */e tur- Durmak, ayakta durmak > Krg. tokto-, tur-

qarar- Kararmak > Krg. karar-

qarg்1ş Beddua > Krg. karg1ş

qar1 Yaşl. bk. qarig > Krg. kar1

qar1- Kocamak, yaşlanmak > Krg. kartay-, kar1-

qarın Karm > Krg. aş kazan, karın

qarındaş Kardes $>$ Krg. ini, karındaş, tuugan 
qarşı I Karşı. bk. qarşu > Krg. karşı; qarşu Karşı. bk. qarşı > Krg. karşı */v

qaş I Ön > Krg. aldı, öñ. kaş "ön, karşı; eyerin ön ve arkasındaki çıkıntılı bölüm"

qaş II Kaş > Krg. kaş

qat- I Katmak > Krg. koş-, kat- "ilave etmek, ilhak etmek"; karıștırmak > Krg. aralaştır-, kat- "ilave etmek"

qatıl- Katılmak, karıșturlmak > Krg. katıl- "saklanmak, gizlenmek" */m

qayna- Kaynamak $>$ Krg. kayna-

qaz Kaz > Krg. kaz

qaz- Kazmak > Krg. kaz-

qaża (A.) Kaza > Krg. avariya, balaket, kaza, ölüm, rayon

qaż̇ (A.) Kadı > Krg. kazı "hakim"

qazıl- Kazılmak > Krg. kazil-

q1l $K$ ll $>$ Krg. k1l

q11- Kılmak, etmek > Krg. k11-, et-, casa-; yapmak > Krg. casa-, k11-

q1liç Kılıc > Krg. kilıç

q1lıq Kılık > Krg. keyip, sırtkı körünüş ; buy > Krg. münöz, peyil, peyli-kuyu, kılık, gidiş > Krg. abal, cürüm-turum, keyip, kilık-coruk

q1lq Huy > Krg. münöz, peyil, peyli-kuyu; gidiş > Krg. abal, cürüm-turum, keyip, kılık-coruk; tavrr, bk. qılıq

$>$ Krg. cürüm-turum $* / \mathbf{v}$

q1lın- Kalinmak, yapılmak, > Krg. kilın- "yapılmak"

q1miz Kimiz > Krg. kimiz

qin I Kin, biçak, ve kilıç kilifi > Krg. kin

q1r I Kır > Krg. ak-sarı, ayıl, boz, talaa, kır "bayır, dağ silsilesi; kenar, sınır, hudut" */m; sabra > Krg. çöl

$* / \mathrm{m}$

q1rìıl Kırçll > Krg. kırgıl "kır sakal" */m

q1rq Kırk, (40) > Krg. kırk üç $\ddot{U} c ̧(3)>$ Krg. üç

q1rtış Yüz > Krg. bet, cüz, üst, kırtı̧ "yüzey, satıh; boya";

q1s- Sikmak, baski altında bulundurmak > Krg. bas-, s1k-, k1s- "sikmak; bask1lamak, zorlamak..."

q1șȘa (A.) Hikêye > Krg. añgeme, ikaya, kissa "kissalar, hikâyeler"

q1ş $K \iota s ̧>$ Krg. k1ş

q1y- Kiymak > Krg. maydala-, kıy- "kıymak, kesmek"

q1yamet (A.) Kiyamet > Krg. kıyamat, kiyamat-kayım

q1y1q Ë̆rilik, cayma > Krg. kıyık "kesinti, kırpıntı" */m

q1yıl- Kiynlmak, kusur islemek > Krg. kıy1l- "kesilmek" */m

q1z I Kiz, kiz cocuk > Krg. k1z

q1z1l Kızıl, kırmızı > Krg. kiz1l, kirmız1

qol I Kol (Tezcan: 'kol' ve 'vadi' anlamlarındaki kol, farklı kelimelerdir görüşündedir. Biz de ayırdık.) > Krg.

bagit, $\boldsymbol{k o l}$, tarmak, tutka

qon- Konmak > Krg. kon- "konmak; yere inmek..."

qor II (Tezcan) Maya (Tezcan) > Krg. kor "iyice mayalanmış boza; esas, bir şeyin özünü oluşturan ana öge, temel" */i

qorq- Korkmak $>$ Krg. kork-

qoş- Yazmak, şiir dü̃mek > Krg. caz-, koş- "ağıt söylemek; doğaçlama şïr söylemek..."

qoşul- Yą̧lmak, düzenlenmek, șïr dürüllmek > Krg. koşul- "bir araya gelmek, katılmak" */m

qoy Koyun > Krg. koy, koyun

quç- Kucaklamak > Krg. kuç- > kuçaktoo */e

qul Kul, köle > Krg. kudaydın kulu, kul "kul, Tanri'ya göre insan; köle"

qulaç Kulaç > Krg. kulaç

qulaq Kulak, bk. qulgaq > Krg. kulak

qulan Yaban eseği $>$ Krg. kulan

qum Kum > Krg. kum

qur- Kurmak > Krg. kur-; germek $>$ Krg. ker-

qurt Kurt, solucan $>$ Krg. kurt, soolcan

qurut Peynir > Krg. kurut "kurutulmuş süzme yoğurt", bıştak, sır

quş Kuş > Krg. kuş

qut Kut, mutluluk, devlet $>$ Krg. kut

qutur- Kudurmak > Krg. kutur-

quzgun Kuzgun > Krg. kuzgun

keç- Geçmek, ölmek > Krg. öl-; keç- "geçmek; affetmek, vazgeçmek" */m

keçiş Geçme > Krg. keçiş

keg (Tezcan: kek olmalı.) Kin > Krg. açuu, kek; öç > Krg. kek, öç, öç aluu */v; hınç, bk. kek > Krg. kektöö $* / \mathbf{v}$

kel- Gelmek > Krg. cet-, kel- 
kelin Gelin > Krg. kelin

kem Hastalık > Krg. ooru, $\mathbf{k e m}$ "eksik, az; geri, aptal" */m

kenç II (F. genc) Haz̧ine > Krg. kazına, kenç"hazine, servet"

kep Kahp > Krg. kalıp, ülgü, $k e p$ "şekil, biçim"; vücut, forma > Krg. beden, dene

ker- Germek, kabartmak > Krg. ker-

kerek Gerek > Krg. kerek

kerim (A.) Kerim > Krg. kerim "kerim, merhametli"

kes- Kesmek > Krg. kes-, toktot-

kesil- Kesilmek > Krg. kesil- "kesilmek; çatlamak, çizgi oluşmak"

kez- Gezmek > Krg. kez-; dolaşmak > Krg. aylan-, çatış-, kez-, tegeren-

kızar- Kızarmak > Krg. kızar-

kim Kim > Krg. kim

kir- Girmek > Krg. kir-

kir Kir > Krg. kir

kişi Kişi > Krg. adam, kişi; insan > Krg. adam, kişi; adam > Krg. adam, kişi; kimse > Krg. ar kim, biröö, kimdir biröö

kişilik İnsanlık > Krg. adamzat, kişilik

köç Göç > Krg. köç

köç- Göcmek > Krg. köç-

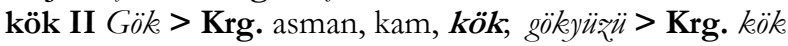

kök III Mavi > Krg. kök; yeşil (Tezcan: 'boz' karşıllı̆ı da eklenmelidir.) > Krg. caş1l

kölük Yük hayvanı > Krg. kölük "binilecek vasıta; deve dışındaki yük hayvanları"

köm- Gömmek > Krg. caş1r-, cerge koy-, köm-

kömül- Gömülmek > Krg. kömül-

kömür Kömür > Krg. kömür

köñül Gönül > Krg. könül

kör- Görmek > Krg. kör-, tikte-

körk Gürellik > Krg. suluuluk, körk "güzellik; görünüş, görünüm."

körül- Görülmek > Krg. körül-

körün- Görünmek, huqura çıkmak > Krg. körün-

körüş- Görüsmek, yüz yüze bakmak > Krg. körüş-

köz Göz. > Krg. köz

küç Güç $>$ Krg. daremet, kıyın, kubat, küç, oor

kül- Gülmek > Krg. kül-

küldür- Güldürmek > Krg. küldür-

kümüş Gümüss > Krg. kümüş

kün II Güneş > Krg. kün

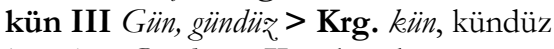

kündüz Gündüz > Krg. kündüz

laqab (A.) lakap > Krg. lakap, lakap at

mal (A.) Mal > Krg. buyum, mal, tovar

ma'ni (A.) Mana, anlam > Krg. maani

men Ben. bk. min > Krg. men

miñ $\operatorname{Bin}(1000)>$ Krg. miñ tümön

miŝâl (A.) Misal, örnek > Krg. misal, örnök, ülgü

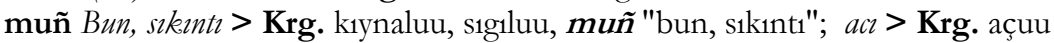

mülk (A.) Memleket > Krg. ölkö, tuulgan cer, mülk "hazine; değer verilen şey; mal mülk" */m

namaz (F.) Namaz > Krg. namaz

ne $\mathrm{Ne}>$ Krg. emne, ne; nasıl > Krg. kanday

neçe Nice $>$ Krg. kança, nece; kaç $>$ Krg. kança, neçe

niyet (A.) Niyet $>$ Krg. niyet

nur (A.) Nur > Krg. carik, nur

oq II Ok> Krg. cebe, ok

on $\mathrm{On}(10)>$ Krg. on

ot I Ateș > Krg. ot

ot III $O t>$ Krg. çöp, em çöp, ot

otuz Otuz. (30) > Krg. otuz

oyun Oyun > Krg. aldoo, ilee, oyun, p'esa, pyesa, teatr oyunu; yarış > Krg. carış

öç $\ddot{O}_{c}>$ Krg. kek, öç, öç aluu; kin $>$ Krg. açuu, kek

öl Islak > Krg. nım, nımduu, suulu, suuluu, öl "nem, 1slaklık, rutubet"; yaş > Krg. caş, kurak, suu; nem >

Krg. nim

öl- Ölmek > Krg. öl- 
ölüm Ölüm > Krg. ölüm

öñ I On > Krg. aldı, ön

öp- Öpmek > Krg. öp-

ör- Örmek; bağlanmak > Krg. ör-

örüm Örülmüss > Krg. örüm "örgü, belik; köy çevresindeki otlak, mera" */m

özel- (Tezcan: üzül- okunmalı) Istırap çekmek > Krg. ürül- "ölmek, can teslim etmek" */m

pak (F.) Pak (temiz) > Krg. pak "pak, tertemiz; günahsı"

peri (F.) Peri $>$ Krg. peri

qaç- Kaçmak > Krg. kaç-; kaçınmak > Krg. baş tart-, çetke çıga ber-; sakınmak > Krg. saktan-

rahat (A.) Rahat $>$ Krg. ıñgayluu, 1raxat, rahat "gönenç, mutluluk, mutlu hayat", tınç

saġizgan Saksağan > Krg. sagizgan

saq Uyanık > Krg. oygoo, sak"uyanık, gözüaçık, müteyakkz; hassas, duyarlı

saqal Sakal > Krg. sakal

sal- Atmak > Krg. ırgit-, taşta-, sal-; bırakmak > Krg. boşot-, kaltır-

saray (F.) Saray $>$ Krg. saray

sat- Satmak $>$ Krg. sat-

sayra- Şakimak, ötüsmek $>$ Krg. sayra-

sebeb (A.) Sebep > Krg. sebep; bahane $>$ Krg. ş1ltoo, tirikçilik

sekirt- Seğirtmek, koșturmak > Krg. bet al-, umtul-, sekirt- "sıçratmak, atlatmak"

semiz Semiz, kuvvetli > Krg. semiz

sen Sen > Krg. sen, siz

sin- Kirlmak > Krg. sin-; bozulmak > Krg. sin-

sina- Sinamak, tecrübe etmek $>$ Krg. sina-

$\operatorname{sir}(\mathbf{r})($ A.) Sir, gizli söz, bk. sir > Krg. sir

sir $S_{i r}>$ Krg. sir

s1z- Sız̆mak > Krg. sız-, sızılıp çık-

siñ- Sinmek > Krg. basın-, siñ- "sinmek, nüfuz etmek; sindirilmek, hazmedilmek; kabullenmek; karışmak"; saklamak > Krg. caşır-, kat-; hazmedilmek > Krg.

siñim (Tezcan: siñimlig "uyumlu, uyum sağlayabilir" olmalı) Kabul (Tezcan: "uyumlu") > Krg. siñimdï̈ü "sindirimi kolay; etkili, saygin" */s

siz Siz > Krg. sen, siler, siz, sizder

soñ Son > Krg. akırkı, soñku, soñ "son, bir şeyin en arkası; -den sonra; arka, art"

sor- I Emmek > Krg. em-, sor-

sök- Sökmek > Krg. sök-, suur-

söz Söz > Krg. söz

sulțan (A.) Sultan $>$ Krg. sultan

sun- Sunmak > Krg. siyla-, sun-; watmak > Krg. uzat-

sür- I Sürmek > Krg. ayda-, boyo-, mayla-, sür-; kovmak, sürgün etmek. > Krg. kubal-, kuu-

süt $S \ddot{u} t>$ Krg. süt

süz- Süzmek $>$ Krg. süz-

süzül- Sü̊ülmek > Krg. arıkta-, süzül- "baygınlaşma, süzülmek; salınarak yürümek; yüzüne nazlı bir anlam

vermek; gözleri süzülmek" */m

şek(k) (A.) Ş̈̈phe > Krg. küdük, kümön, şek"kuşku, şüphe; ima", şektenüü

şeker (F.) Seker > Krg. kant, kemput, şeker

şerab (A.) İ çki, şarap > Krg. içimdik, içkilik; şarap

şiş Şiş (Tezcan: Bu anlam çıkarılmalıdır.) > Krg. şiş, şişik

ta at (A.) İbadet > Krg. ibadat, kudayga siyınuu, tabinuu, taat "taat, ibadet; sabir"

tal Dal > Krg. butak, salaa, şak, tarmak, tal"dal; söğüt ağac1"

tala- Yağma etmek > Krg. tala- "dalamak, köpek 1sırmak; yemek, 1sırmak; mec. Talan etmek."

tamam (A.) Tamam, tamamlanmış > Krg. büt, cakşı, carayt, makul, toluk; tamam "son; tamam, bütün, tüm"

tamġa Damga, mübür > Krg. tamga, möör

tamgala- Damgalamak, mübürlemek > Krg. tamgala- "damga vurmak; hecelemek", möör bas-

tañ Şasıllacak, acayip şey > Krg. tañ (kal-)

tañ Tan, sabah vakti > Krg. tañ

tara- Taramak $>$ Krg. tara-

taran- Taranmak $>$ Krg. taran-

țariqat (A.) tarikat $>$ Krg. tarikat

tart- Tartmak > Krg. tart-; çekmek $>$ Krg. tart-; uratmak $>$ Krg. uzat-

taş I Tas $>$ Krg. taş

tat- Tatmak $>$ Krg. daam tat-, tat-

tay Tay $>$ Krg. tay 
tayan- Dayanmak > Krg. tayan- "dayanmak, güvenmek"

tayaq Dayak, değnek > Krg. tirööç, türkük, çıbık, tayak, tayakça

tazı (F. tåi) Tazı, Arap atı > Krg. añçı it, tazı

teke Geyik (Tezcan: "erkek dağ keçisi" olarak düzeltilmelidir.) > Krg. bugu, maral, teke "erkek keçi"

ten (F.) Ten, vücut $>$ Krg. beden, dene, ten

teñ Denk, benžer; akran > Krg. barabar, cük, cüktün teñi, teñ ; kurdaş

teñeş- Denkleşmek > Krg. teñeş- "boy ölçüşmek; uymak, uygun olmak"

tep- Tepmek > Krg. tep-; vurmak, dögmek > Krg. at-, ur-

ter $\ddot{U}$ cret $>$ Krg. emgek ak1, ter"ter" */m

ters Ters $>$ Krg. ters

teş- Deşmek $>$ Krg. teş-

tetik Zeki > Krg. zeendüü, zirek, tetik"çabuk davranan, çevik, dikkatli, uyanık" */m

tın Rub > Krg. rux, şaytan, tın"nefes; (eski) can"

tik- Dikmek, dikey getirmek > Krg. ek-, ornot-, say-, tik-; (dikis) dikmek > Krg. ek-, ornot-, say-, tik-; (ăgac)

dikmek $>$ Krg. ek-, ornot-, say-, tik-

tiken Diken $>$ Krg. tiken

til Dil > Krg. til; söæ, lügat > Krg. söz

tile- Dilemek $>$ Krg. tile-; istemek $>$ Krg. kaala-, tile-

tilek Dilek $>$ Krg. tilek

tilen- Dilemek $>$ Krg. tilen-

tiril- Dirilmek, yaşamak > Krg. tiril-; caşa-

tiş Diş > Krg. tiş

tiz- Dizmek > Krg. kitatta-, tiz-

tizil- Dizilmek > Krg. tizil-

toq Tok $>$ Krg. tok

tol- Dolmak $>$ Krg. tol-

toñ- Donmak > Krg. toñ-

ton Elbise > Krg. ton "kiyim, kostyum, ton; hayvan postundan yapılmış mont; mont; ört

toy II Halk, topluluk > Krg. el, curt, kalk, camaat, koom, toy"toy, düğ̈ün; eğlence merasimi" */m

toz Toz > Krg. çañ, toz

toz- Tozyükselmek, tozmak > Krg. toz- "ufalanıp toz olmak; dağıllp yok olmak; eskimek" */m

tök- Dökmek > Krg. koy-, kuy-, tök-

tört Dört (4) > Krg. tört

tul Dul > Krg. cesir, tul

tuman Duman, sis > Krg. tuman, tütün

turan (y.a.) Turan $>$ Krg. turan

turna Turna $>$ Krg. turna

tuşa- Köstek vurmak > Krg. tuşa- "bukağı vurmak, ayaklarını bağlamak"

tut- Tutmak, > Krg. cakala-, karma-, sakta-, tut-

tutam Tutam $>$ Krg. çımçım, tutam

tutul- Tutulmak $>$ Krg. tutul-

tutun- Tutunmak $>$ Krg. tutun- "kendi çocuğu gibi tutmak, kabullenmek" */m

tuz Tuz $>$ Krg. tuz

tuzaq Tuzak > Krg. tuzak

tuzaqçı Tuzakȩı, tuqak kuran > Krg. tuzakçı

tümen Pek, çok, on bin > Krg. tümen "on bin; çok sayıda, fazla"

tün Gece > Krg. tün

tüp Dip > Krg. tüp

tüptüz Düpdüz > Krg. tüp-tüz

tür- Dürmek > Krg. oro-, tür-

tüş Düs, rüya (Tezcan: tüş 'düş, rüya' verileri arasında yer alan tüşte 5177'de tüş 'konak yeri, menzil' anlamındadır. Arat da böyle çevirmiştir. Ayrı madde başı yapılmalıdır. Aynı madde verilerinden tüş 3571

'karşllık, ürün, meyve' anlamındadır.) > Krg. tüş

tüş- Düsmek > Krg. cig1l-, kula-, tüş-

tüşür- Düşürmek > Krg. tüşür- "düşürmek, indirmek"

tütün Duman > Krg. tuman, tütün

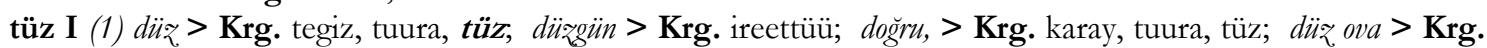
tüz "düz arazi, ova"

uç $U_{c}>$ Krg. uç; tepe > Krg. döbö

uç- Ucmak > Krg. uç-

uçmak cennet $>$ Krg. beyiş, cannat, uçmak

uçur- Uçurmak > Krg. uçur- 
ula- Bağlamak, eklemek (Tezcan: Veriler arasında bulunan ular 75 'keklik' anlamında olup tabii ayrı bir maddebaşı yapılmalıdır.) > Krg. bayla-, bekit-; koş-, ula-

ulan- Ulaşmak, bağlanmak > Krg. cet-, ulan- "ulanmak, devam etmek"

ular (Tezcan) Keklik > Krg. ular "çil kekliği" */i

ulaş- Ulaşmak > Krg. cet-, ulaş- "ulaşmak, erişmek"

una- Razı olmak > Krg. makuldaş-, una- "onamak, uygun görmek, kabul etmek, tasvip etmek"

ur- Vurmak, > Krg. at-, ur-; dövmek > Krg. canç-, maydala-, sok-, tokmokto-, ur-

urun- Vurunmak, takinmak, örtünmek, giyinmek > Krg. urun- "çarpmak; değmek, dokunmak, temas etmek; faydalanmak; karışmak, bulaşmak; gelmek, ulaşmak; uğramak, varmak; göze çarpmak, fark edilmek" */m

uruş V uruş, savaş > Krg. soğuş, uruş

uruş- Vuruşmak, savaşmak > Krg. soğuş-, uruş-

uşaq I Kücük > Krg. kiçine, kiçinekey, uşak

ut- Yenmek $>$ Krg. ceñ-, ut-

uz Usta > Krg. usta, uz "usta, usman; maharetli, becerikli kadın"; mabir > Krg. çeber, ustat

uza- Uzamak > Krg. sozul-, uza- "uzaklaşmak; yönelmek", uzar- **/k

uzaq Urak > Krg. alis, uzak

uzat- Uzatmak > Krg. uzat-

uzatıl- Uzatılmak > Krg. uzatıl- "verilmek; kız kocaya verilmek, evlendirilmek; birisi uğurlanmak" */m

uzun u₹un > Krg. uzun

üçün İ̧in > Krg. üçün

ülüş Hisse, pay > Krg. ülüş, pay; nasip, kısmet > Krg. nasip

ün Ses $>$ Krg. dabiş, dobuş, ün

ür- I Havlamak > Krg. kap-, ür

üst Üst > Krg. üst

üz- Kesmek > Krg. kes-, toktot-, üz- "Koparmak, kesmek; durdurmak"

üzül- Kesilmek, kirlmak; parçalanmak > Krg. açuulan-, üzül- "Kopmak; kesmek, durdurmak; ölmek, sona ermek"

vacib (A.) Vacip, yapılması șeriat bakımından gerekli olan > Krg. kerektik, vacip

zina (A.) Zina > Krg. zina

\section{Anlam Değişmesine Uğrayan Kelimeler}

Günümüz Kırgız Türkçesinde yaşayan Kutadgu Bilig'deki 1543 adet kelimenin içinde, anlam değişmesine uğrayan kelimeler bulunduğunu yukarıda belirtmiştik. Bunlar, anlam genişlemesi, anlam daralması, mecazlaşma gibi değişmelerin tezahür ettiği kelimelerdir. Bunlar çalışmamızda */m şeklinde işaretlenmiştir. Tespit edebildiğimiz örnekler şunlardır (örneklerde zaman zaman ses değişmeleri de görülmektedir):

ag̀ru- Ağrlaşmak > Krg. ooru- "ağrımak; hastalanmak" */m

alış- Beraber etmek, beraberce yapmak, paylaşmak; (Tezcan: "alış verişte bulunmak") > Krg. alış- "savaşmak, mücadele etmek; atışmak", bölüş- */m

apa Âdem, insan, adam > Krg. adam, kişi, apa "anne" */m

așlı (A. asli) Asli, asli olan > Krg. asıl "asil, has..." */m

atçı (Tezcan: etçi "kasap, mecazen Azrail") Süvari > Krg. atçan, atçı "seyis" */m

baqın- Bakınmak > Krg. bagın- "baş eğmek; yenilmek" */m

bilin- Bilmek, anlamak > Krg. bilin- "bilinmek", bil-, anda-, tüşün- */m

biliş- Bilişmek, tanışmak > Krg. biliş- "tanınmış olmak, aşikâr olmak" */m

boġuz Boğa $>$ Krg. bogooz "pis ağızlı", tamak, alkın */m

bük Kösse bucak > Krg. bük "büküm, kat, kıvrım" */m

bütür- Sağaltmak, sağlam hâle koymak > Krg. bütür- "bitirmek, tüketmek; mezun olmak" */m

çap- Yüzmek > Krg. sıyır-, süz-, çap- "kırbaçlamak; kesmek, biçmek; yok ve imha etmek; dörtnala koşmak" $* / \mathrm{m}$

eḍülük İyilik > Krg. cakşılık, iygilik"başarı" */m

eligleş- Elleşmek, el sıkışmak, tokalașmak > Krg. eldeş- "barışmak" */m

emçi Tabip > Krg. tabıp, emçi"üfürükçü" */m

erdem Erdem, farilet > Krg. coomarttık, tatıktuuluk; erdem "yiğit, er, kahraman" */m

esenleş- Esenlik dilemek, vedalaşmak > Krg. koştoş-, esendeş- "selamlaşmak" */m

ewçi Kadın > Krg. ayal, katın; epçi"çadırın kadınlara ait kısmı, haremlik" */m

hat Hat, çizgi, yaz! > Krg. cazuu, qat"mektup" */m

içim İcecek > Krg. suusunduk, içim "yudum" */m

iniş Iniş > Krg. eñis "havza, çukur yer" */m

qap- Tutmak > Krg. cakala-, karma-, sakta-, tut-, kap- "köpek 1sırmak; ağır konuşmak, sözle saldırmak" */m 
qat1l- Katılmak, karıstırlmak > Krg. katıl- "saklanmak, gizlenmek" */m

qawuq Kepek, > Krg. kebek, kabik"kabuk; sidik torbası" */m

keç- Geçmek, ölmek > Krg. öl-; keç- "geçmek; affetmek, vazgeçmek" */m

kem Hastalık > Krg. ooru, kem "eksik, az; geri, aptal" */m

q1r I Kır > Krg. ak-sarı, ayıl, boz, talaa, kır"bayır, dağ silsilesi; kenar, sınır, hudut"; sabra > Krg. çöl */m

q1rg்1 Kirçl > Krg. kırgil "kır sakal" */m

q1y1l- Kinnlmak, kusur islemek > Krg. k1yıl- "kesilmek" */m

q1yı Ë̆rilik, cayma > Krg. kıyık "kesinti, kırpıntı" */m

kiçe Gece > Krg. tün, keçe"dün" */m

qoşul- Yąılmak, düzenlenmek, siir düzülmek > Krg. koşuluu "bir araya gelmek, katılmak" */m

kökle- Bir işin esasina vâkıf olmak (Tezcan: Bu karşıllğın yerine Clauson 711 kökle- (2)'de önerildiği gibi 'saç1 ağarmak' alınmalıdır...) > Krg. köktö- "bitki yeşermek; hayvan otlamak; iş yolunda gitmek; dikmek, teğellemek" */m

könek Kova burcu > Krg. könök "kırba, kap, kova" */m

qurugisaq Gönül (Tezcan: Tabii burada 'mide, karın' anlamına gelen sözcüğün (TT. kursak) mecazlı kullanımı söz konusudur...) > Krg. köñül, kursak"kursak, karın, mide; iştah" */m

mülk (A.) Memleket > Krg. ölkö, tuulgan cer, mülk "hazine; değer verilen şey; mal mülk" */m

müsafir (A.) Yolcu > Krg. colooçu, cürgünçü; musapır"zavalli, gariban" */m

nevbet (A.) Resmîyerlerde belli zamanlarda çalınan davul > Krg. nöömöt "nöbet, sıra" */m

örüm Örülmüss > Krg. örüm "örgü, belik; köy çevresindeki otlak, mera" */m

öte- Ödemek > Krg. tölöö, ötö- "yapmak, yerine getirmek" */m

ötel- Ödenmek > Krg. ötöl- "yapılmak" */m

öwke Öfke, kıəginlık > Krg. açuu, öpkö "gücenme, kırgınlık; akciğer" */m

özel- (Tezcan: üzül- okunmalı) Istrrap çekmek. > Krg. üzül- "ölmek, can teslim etmek" */m

rahmet (A.) Rahmet > Krg. ırakmat "teşekkür, sağol" */m

sinag Sinanmıs, tecrübe edilmiş > Krg. sinoo "sinav, deneme, prova"; sinak "sinav; zor durum; yarışma" */m

suwla- Su icmek > Krg. suula- "1slatmak, 1slak duruma getirmek" */m

suwlan- Sulanmak, > Krg. suulan- "1slanmak" */m

süçig Tath > Krg. tattuu, tattuu tamak, çuçuk"et sucuğu" */m

süzül- Süzülmek > Krg. arıktoo, süzül- "baygınlaşma, süzülmek; salınarak yürümek; yüzüne nazlı bir anlam vermek; gözleri süzülmek" */m

taqșir (A.) Kusur > Krg. az ayıp, kusur, taksır"büyüklere saygı sözü; efendim" */m

ter $\ddot{U}$ cret $>$ Krg. emgek ak1, ter"ter" */m

tetik Zeki > Krg. zeendüu, zirek, tetik"çabuk davranan, çevik, dikkatli, uyanık"; akıllı > Krg. akılduu */m

toñ sert, katı > Krg. katuu, toñ "don, buz tutma; ham, olmamış; soğuk, ilgisiz" */m

toy II Halk, topluluk > Krg. el, curt, kalk, camaat, koom, toy"toy, düğün; eğlence merasimi" */m

toz- Tozyüleselmek, tožmak > Krg. toz- "ufalanıp toz olmak; dağıllp yok olmak; eskimek" */m

törüt- Yaratmak > Krg. caratuu, töröt- "ortaya çıkmasina sebep olmak; doğurtmak" */m

tutun- Tutunmak > Krg. tutun- "kendi çocuğu gibi tutmak, kabullenmek" */m

tünek Zindan > Krg. zından, tünök "hayvanların, kuşların gece yattıkları yer, ahır, yuva" */m

urun- Vurunmak, takınmak, örtünmek, giyinmek > Krg. urun- "çarpmak; değmek, dokunmak, temas etmek;

faydalanmak; karışmak, bulaşmak; gelmek, ulaşmak; uğramak, varmak; göze çarpmak, fark edilmek" */m

uzatıl- Uzatılmak > Krg. uzatıl- "verilmek; kız kocaya verilmek, evlendirilmek; birisi uğurlanmak" */m

yarag Imkân; firsat; fayda > Krg. mümkündük; pursat; payda, carak"Araç gereç, alet; silah" */m

yarın II Omu₹ > Krg. iyin, coorun "sırt, sırt kemiği; omurga" */m

yulun- Kurtarmak > Krg. kutkaruu, çulun- "çırpınmak; bulunduğu yerden ileri doğru atılmak, firlamak; dizginlenememek, koşmaya çalışmak; sinirlenip dövüşmeye kalkışmak", culkun- */m

zinet (A.) Ziynet, süs, bę̧ek > Krg. monçok, zıynat "sayg1, hürmet gösterme", casalga, azem, casalga, şurumonçok $* / \mathrm{m}$

\section{Kısmen Değişen Kelimeler}

Kutadgu Bilig'deki kelimelerden bir kısmı, Bugünkü Kırgız Türkçesinde kısmen yapı değişikliğiyle yaşamaya devam etmektedir. Bunların birçoğunda işlevi aynı olan ek farklılı̆̆ görülmektedir. Bu durum aslında sadece Kırgız Türkçesine özgü olmayıp başka çağdaş Türk lehçelerinde de görülebilmektedir. Kırgız Türkçesindeki örnekler şunlardır (Bu örneler */k şeklinde işaretlenmiştir):

\subsection{Kelimedeki Bir Ekin (genellikle aynı işlevde) Eksik veya Fazlalı̆̆1}

adır-t- Ayrrtmak, ayrt etmek, > Krg. ayır- "ayırmak, ayırt etmek"; acırat- */k

'adil (A.) Adalet; doğruluk $>\mathbf{K r g}$. adil +dik, adilet */k

aş + ç1 $A$ ş̧ $>$ Krg. aşpoz, aş + poz + çu $* / \mathbf{k}$

gazi+lik Gazilik > Krg. kaz1 "gazi" sözü var*/k

qam- Kamaşmak > Krg. tişin kama-, kama- "kamaşmak" */k 
tog்ur- Doğurmak > Krg. tuu- $* / \mathbf{k}$

toqluq Tokluk, tok olma > Krg. tok +çu+luk "bolluk, bereket, feyiz" (+lIk ekinin işlevini, bazen kalıplaşmış bir

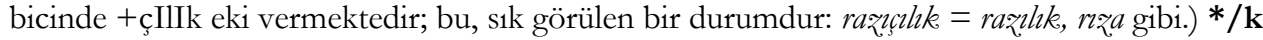

uza- Uzamak > Krg. sozul-, uza- "uzaklaşmak; yönelmek", uzar-*/k

yalıñ Ciplak > Krg. cılañ + aç */k

yap-çu- (Tezcan: Maddebaşı yapuş- olmalıydı. yapuş-ur $>$ yapşur $>$ yapçur gelişmesiyle ortaya çıkan çekimli biçime dayanarak yapçu- eyleminin varlığı kabul edilemez.) Yapısmak > Krg. cabışuu, capışuu, capş1-r"Çiğnemek, ezmek; Saklamak, gizlemek, örtbas etmek" */k

yir- Yermek, beğenmemek, hakir görmek > Krg. camanda-, cer-i- "kabullenmemek, reddetmek; beğenmemek, nefret etmek" */k

yol+çı Yolcu; rehber (Tezcan: Bu karşılık çıkartılarak yerine 'kılavuz, yol gösterici' alınmalıdır. Arat da böyle çevirmiştir.) > Krg. $\boldsymbol{c o l}+\boldsymbol{o o}+\boldsymbol{c} \boldsymbol{u}(<$ yol $+\mathrm{ag}(+\mathrm{aw})+$ çı), cürgünçü; gid, col körsötüüçü */k

\subsection{Aynı İslevdeki Bir Ekin Farklı Oluşu}

Fiilden fiil yapan ettirgenlik ekleri, Kutadgu Bilig metni ile günümüz Kırg1z Türkçesinde farklı kullanımla karşımıza çıkabilmektedir. Örneğin $-t$ - yerine-z;, $-d U r$, $-g I r$; $-g U r$ - yerine $-g I_{₹}$ eklerinin kullanılması gibi. Ettirgenlik eklerinin Türk lehçelerinde farklı tercihlerde kullanılıyor olması, esasen yeni bir durum değildir. Hem tarihî hem de günümüz Türk lehçelerinde bu durumu müşahade edebilmekteyiz. Örnekler içinde, hem Kutadgu Bilig'deki şeklini koruyan hem de aşağıda belirtilen değişikliğe uğrayanlar da mevcuttur. Yapısındaki ek farklılığılyla ilgili olan kelimeleri "kısmi değişiklik" anlamında $* / \mathbf{k}$ ile işaretledik. Bunlar arasında mana değişikliğine uğrayanlar da mevcuttur. Bunları da */k-m şeklinde gösterdik.

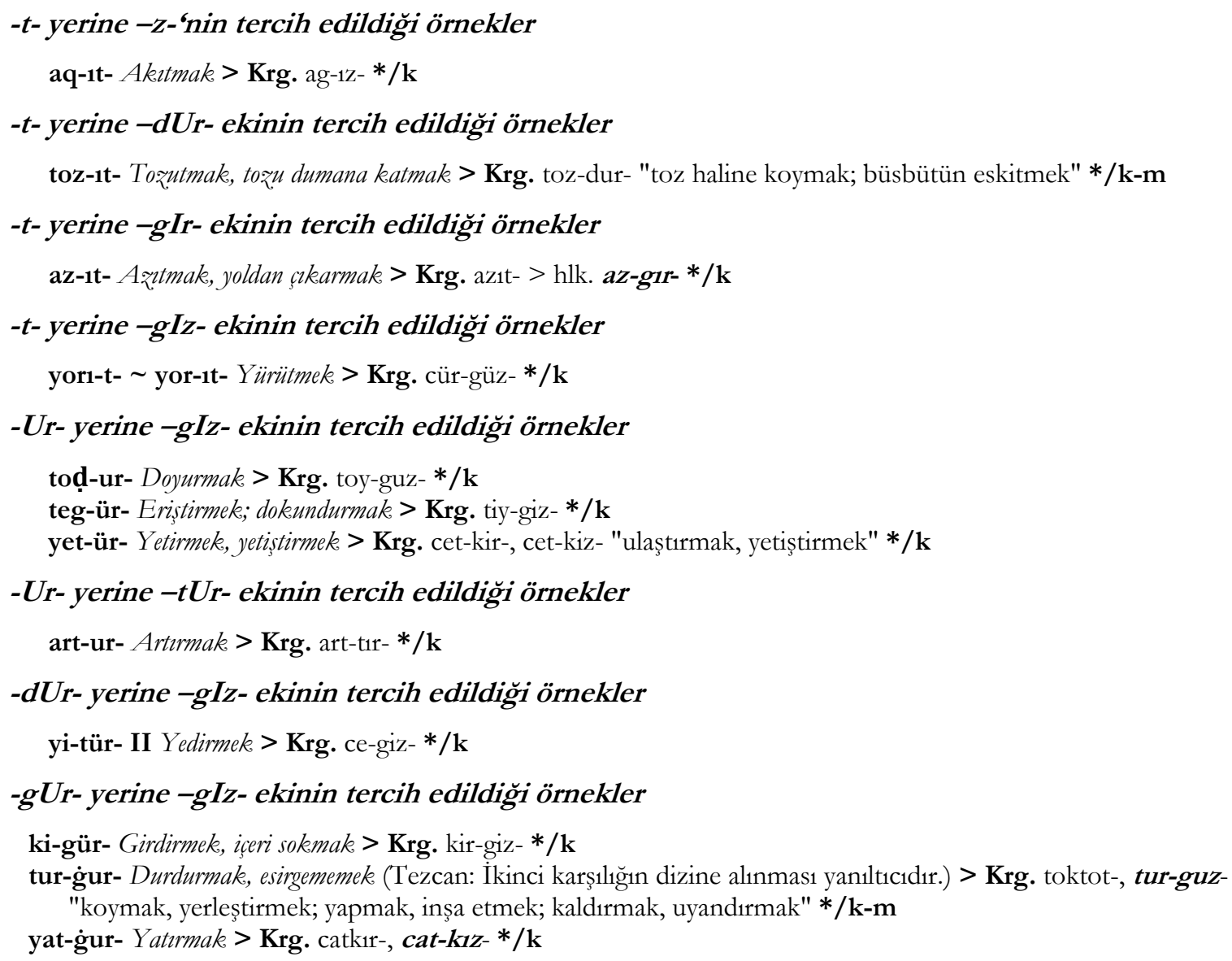

\subsection{Diğer Eklerdeki Farklıhklar}

Aşağıdaki örnekler, bazı isim veya fiil köklerinden / gövdelerinden, işlevi aynı veya yakın olan farklı eklerle yeni kelimeler yapıldığı göstermektedir. Örneğin edilgenlik işlevindeki -n- yerine Kırgız Türkçesinde -l'nnin; isimden isim yapan $+c ̧ I$ eki yerine aynı işlevi karşılayacak şekilde $+c ̧ I l$, Farsça + ker, Farsça +göy eklerinin kullanılması gibi. Örnekler, eke göre değil, alfabetik sıralamaya göre verilmiştir.

az+la- Az görmek, azımsamak. > Krg. az+sin- */k

bulgan-uq Bulanı > Krg. bulgan-1ç, kir, kirgil */k 
bul-ul- Bulunmak > Krg. bol-, bul-un- "bulunmak" */k

du'a+çı Duacı, dua eden > Krg. duba+ker, duba+köy $* / \mathbf{k}$

hind $+\hat{\mathbf{1}}$ (F.) Hintli $>$ Krg. indiya + lık $* / \mathbf{k}$

hindu (A.) Hind $+u>\mathbf{K r g}$. indiya + lık $* / \mathbf{k}$

iç+re İcerisinde, içinde $>\mathbf{K r g}$. iç + keri $* / \mathbf{k}$

iç-güçi İckeiye mübtela > Krg. iç-kiç */k

iz+le- İlemek, takip etmek > Krg. iz+de- "aramak, araştırmak", iz kuu "iz sürmek, takip etmek" */k

qaq+1la- Kaحlarm "gak. gak" diye bağrışması > Krg. kak+1lda- */k

qur1- Kurumak > Krg. kurga-

oq1-n- Okunmak > Krg. oku-l- */k

töşe-n- Dösenmek > Krg. töşö-l- */k

uyaḍ- Utanmak > Krg. uyal- */k

üst+e-ñ Üstün, galip > Krg. cogorku, mıkt1; ceñüüçü, utuuçu, üst+ö-m "Otorite, üstün güç" */k

yañl-uq Yanls, > Krg. cañıl-1ş, kata */k

yor-g்u+çı Tabir eden, yoran $>$ Krg. cor-um + çu "yorumcu" */k

yun- Yunmak, yıkanmak, > Krg. cuun-, cuu-1- */k

yük+çi Yük, taşıyan > Krg. cük +çül */k

\subsection{Kelime Kökünde, Gövdesinde Ses Düşmesi, Ses (ek) Değişmesi veya Genişleme Sebebiyle Oluşan Farklilı}

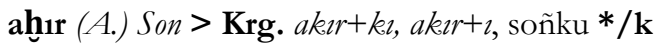

'aleyk (A.) Senin ürerine olsun 'a. al- "selam almak”, 'a. bir- "selama cevap vermek." > Krg. alik "selamlaşmaya karşı verilen cevap"

berk+it- Perkitmek, sağlamlastırmak > Krg. bek+it- */k

bür+kir- Püskürmek > Krg. büş+kür- (yansıma kök) */k

iriglen- Yüz, cevirmek; gadretmek, sertlik, göstermek > Krg. ciyirken- "iğrenmek; beğenmemek" */k-m

qara+r-t- Karartmak $>$ Krg. kara+y-t- $* / \mathbf{k}$

qazna+q Haz̧ine (Tezcan: Arapça ḩazîna'nın Orta İran dillerinden birinin aracıllŏıyla ödünçlenmiş biçimidir.)

$>$ Krg. kazina $* / \mathbf{k}$

qoru- Korumak $>$ Krg. aşıra-, bak-, korgo- $(<$ korga- $) * / \mathbf{k}$

küz+ünü küz+üngü Ayna $>$ Krg. küz+gü $* / \mathbf{k}$

oḍan- Uyanmak. bk. oḍun- > Krg. oygon- */k

oḍigr- Uyandirmak > Krg. oygot- $* / \mathbf{k}$

oḍun- Uyanmak, bk. oḍan- > Krg. oygon- */k

ö1+i- Islanmak $>$ Krg. öl boluu, suu boluu $* / \mathbf{k}(+i$ - IFYE ile değil, bol- filili ile fiilleştirilmiş.)

öt+le- Öğ̈̈t vermek, nasihat etmek > Krg. ögüt+tö- "propaganda yapmak" */k

tol-u+luq Doluluk > Krg. tol-uk+tuk "doluluk, tamlık; semizlik, tombulluk; külliyet" */k

uş İste > Krg. mına, minake, oş+o, oş + ol "O" */k

yirin- İgrenmek $>$ Krg. ciyirken- $* / \mathbf{k}$

\section{Eskimiş Kelimeler}

Kutadgu Bilig'deki bazı kelimeler, Kırgız Türkçesinde eskimiş hâlde yaşamaktadır. Bunların birçoğunda kök eskimiș, ama o kökten türetilen gövde kullanılmaktadır (Bu durum diğer Türk lehçelerinde de görülür). Bazı kelimenin eskidiğine dair bilgi, Kırgız sözlüklerinde (kısaltma ile) kaydedilmiştir. Tespit edebildiğimiz örnekler şunlardır (Bu eskimiş kelimeler*/e şeklinde işaretlenmiştir):

ar- II Yorulmak, dermansız kalmak > Krg. çarca-, ar-ı- "yorulmak" */e

ay- Demek, söylemek > Krg. ay-t-, süylö- */e

bayat Kadim (Tanr) > Krg. bayata+dan / bayat+dan "son günlerde", bayata+dan / bayat+dan beri "öteden beri" */e

qarar (A.) Karar > Krg. çeçim, toktom, karar"karar, yarg1" (eski) */e

kiñü- Genislemek > Krg. keñi- bk. > keñey- */e

köpek Köpek > Krg. it, köpök (eski)*/e

quç- Kucaklamak > Krg. kuç- bkz. > kuçak+ta- */e

törü- Türemek, meydana gelmek. bk. töri- > Krg. payda boluu, töröl- "doğmak, dünyaya gelmek" */e

tüg- Catmak > Krg. çataktaş-, çat-, kaarına al-, kıcırı kayna-, tireştir-, uçtaştır-; bağlamak > Krg. bayla-, bekit-, tüy

tüke- Tükenmek, > Krg. büt-, tügön-; bitmek $>$ Krg. ayakta-, büt- */e

ud1- Uyumak > Krg. ukta- (< uyu-ku+la- > uyku+la- > ukla- > ukta- uktoo) */e

yirinçig Tiksinti verici, iğrenç $>$ Krg. ciyirkendi "iğrenç, tiksinti verici, mide bulandırıcı", ciyirkeniç"Tiksinme, iğrenme; beğenmeme, nefret etme", ciyirkeniçtüü */e 
yişin Çökük, çökmüs (Tezcan: ... Kutadgu Bilig 'deki sözcügü yışın okumak ve yışı- eyleminden - $n$ ile bir sıfat olarak açıklamak gerekir, dizinde verilen anlam uygundur, der.) > Krg. krş. c1şı- "sararıp solmak, çökkün görünmek" */e

zamane (A.) Zamane > Krg. azırkı, bügünkü, zamanası kuurul-/tarı- "çaresiz kalmak" deyimi içinde. */e

\section{Yaygın Ses Değişmeleri}

Kıpçak Türkçelerinin (Kırgız, Kazak, Karakalpak, Tatar, Karaçay, Malkar vd.) genel özelliği olan (genellikle) kelime / hece sonu $-(I) \dot{\boldsymbol{g}} /-(\boldsymbol{I}) \boldsymbol{g}$ seslerinin $-(I) w^{\prime}$ ye dönmesi (eköö < ikegü, üçöö < üçegü örneğinde hece ortası) genel bir kuraldır. Kırgız Türkçesinde bu $-(I) w$ sesi, vokalize olarak $u$, $\ddot{u}, o$, $\ddot{o}$ seslerine döner. Kutadgu Bilig'de bulunan bu yapıda kelimelerin söz konusu kurala göre Kırgız Türkçesindeki değişmiş örnekleri şunlardır:

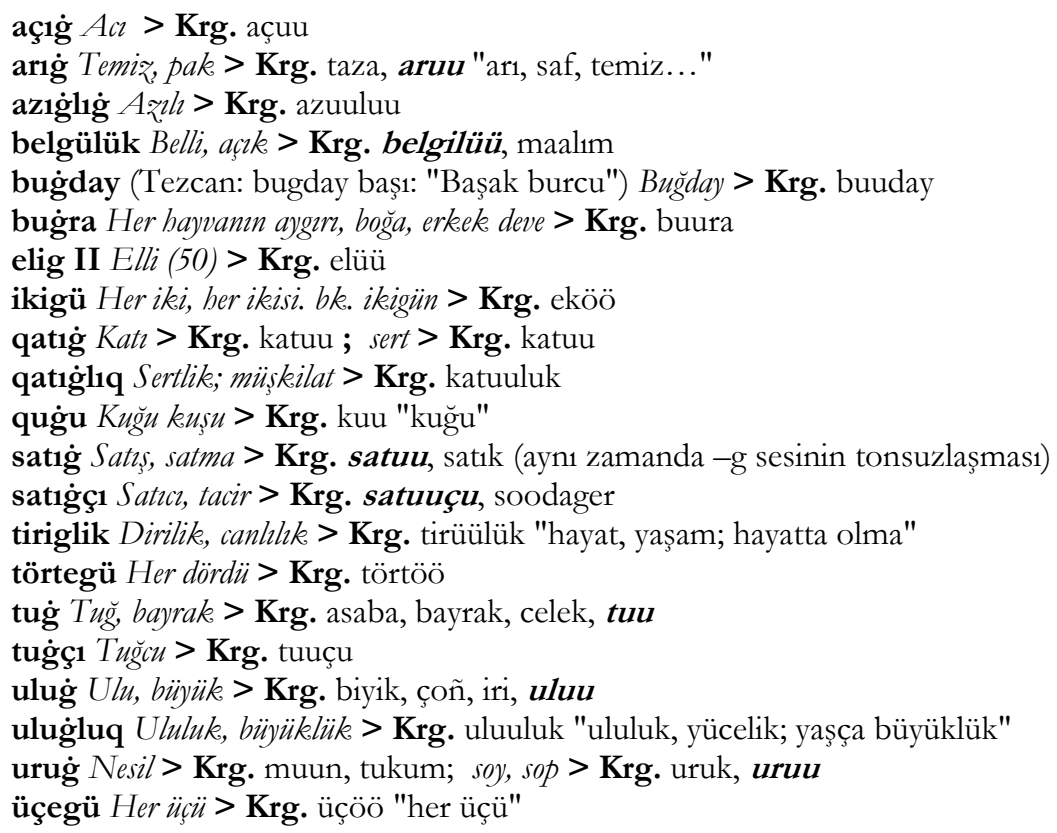

Kutadgu Bilig'deki $\mathrm{b}>\mathrm{w}$ değişmesine uğrayan kelimelerdeki söz konusu $w$ de vokalize olma kuralının dışında kalmaz:

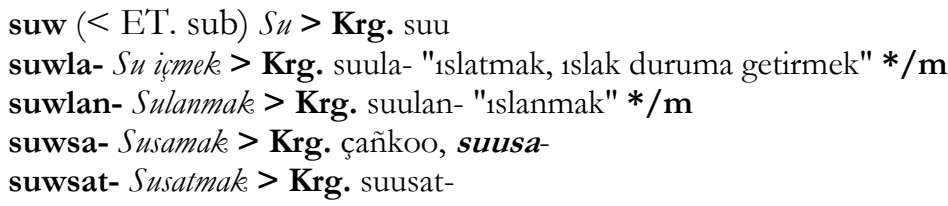

Kutadgu Bilig kadrosundaki kelimelerde bulunan $a g$, og, $u g$ ses grupları, Kırgız Türkçesinde oo veya kelimede bulunan $u$ sesinin varllğıla $u u$ ses grubuna döner (ag $>$ aw $>$ oo). İnce siradan $e g$ ses grubu da

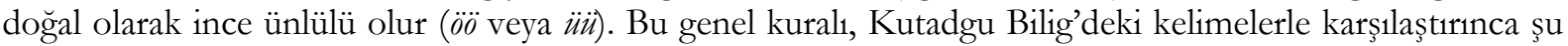
örnekleri görmekteyiz:

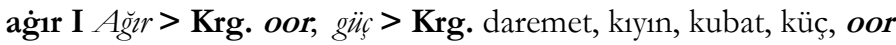

ag̀1z $A \breve{g r z}>$ Krg. oOz

à̈r1- A ğrmak > Krg. keselde-, ooru-, oorlo- "Güçleşmek, zor olmak"

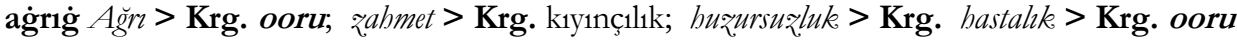

ag்r1t- Agrntmak > Krg. oorut-

ag்ru- Ağırlaşmak > Krg. ooru- "ağrımak; hastalanmak" */m

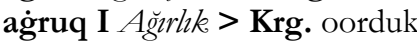

ag̀u Zehir $>$ Krg. uu, zaar

ağına- Debelenmek. (Tezcan: ag(1)na-) > Krg. aldas ur-, jan talaş-, tıpıra-, oono-

bag II Bă̆, dügüm bağlayacak, ip > Krg. boo, cip

baġdaş Bağdaş > Krg. mandaş

baġır Bağır, karaciğer > Krg. boor, kökürök

baġ̀şla- Bağışlamak > Krg. bagışta- "adamak, ithaf etmek; nezretmek" kömöktöş-

baġlan- Bağlanmak > Krg. baylan- 
bog்- Boğmak > Krg. buu-, tumçuktur- (Kutadgu Bilig İndeks’inde bog- şeklinde kayıtlı olan kelimenin buǵokunabileceğini de belirtmek gerekir. Nitekim Türk lehçelerinin birçoğunda kelimenin ünlüsü $u$ 'dur.) qaġun Kavun > Krg. koon

oġlan Oğlan, oğul > Krg. erkek bala, uul; çocuk > Krg. bala; genç, bk. oggul > Krg. caş

og̀r1 Hirsız > Krg. uuru, uuru-keski, üy tonooçu

og̈r1liq Hirsız̆lk $>$ Krg. uuruluk

otag Otağ, çadır > Krg. boz üy, çatır, otoo "küçük keçe çadır; gelin çadırı"

sınag Sınanmıs, tecrübe edilmiş > Krg. sınoo "sınav, deneme, prova"; sınak "sınav; zor durum; yarışma" */m sog்1q Soğuk. bk. soġuq > Krg. suuk */v (Bu kelimenin ilk ünlüsünün Arap harfli yazıya göre sug̉ı biçiminde u'lu okunması da mümkündür.)

sogiuq Soğuk. bk. sogiqq > Krg. suuk */v

tag $D a \check{g}>$ Krg. too

toğru Doğru, > Krg. karay, tuura, tüz

tog்ul- Doğmak, sulbünden gelmek, > Krg. ç1k-, töröl-, tuu-, tuul-

tuşag Köstek, bukăğ > Krg. çider, tuşoo

yog்un Kalın, yoğun > Krg. coon, kalıñ; c1ş, köp

$a w \sim a v \sim e v$, ow ses gruplar1, tam vokalize olarak $u$ veya oo ses grubuna döner:

awuç Avuc bk. Awnt > Krg. uuç */v

awut $A$ vuc. bk. awuc $>\mathbf{K r g}$. uuç */v

cevab (A.) Cevap > Krg. coop

da'vi (A.) Dava, iddia > Krg. arız, doo, doomat, 1yık kaaloo, ümüt, 1rastoo, oyunda turuu

devlet (A.) Babt $>$ Krg. bakıt, kut, taalay, döölöt, talih $>$ Krg. cazmış, tagdır; saadet $>$ Krg. baktıluuluk,

döölöt; devlet > Krg. mamleket; ikbal > Krg.

qawşur- Kavusturmak > Krg. kuuşur-

qow- Kovmak > Krg. kubala-, kuu-; sürmek > Krg. ayda-, boyo-, mayla-, sür-

qow1 $\dot{I}_{c} i$ boss, kof > Krg. kuu çiren

yawaş Yumusake buylu > Krg. cooş

\section{6. Ünsüzler}

\section{1. Ünsüz Değişmeleri}

Kutadgu Bilig'deki bir kısım kelimelerin bünyesinde bulunan ünsüzler, günümüz Kırg1z yazı dilinde değişmelere uğramış olarak karşımıza çıkar. Bu değişmelerin bir kısmı ton (titreşim) bakımından benzeşme kuralının sonucudur. Diğer bazı Türk lehçelerinde de görülen bu durum, Kırgız Türkçesinde de çok sık, hatta kural olarak karşımıza çıkar. Sert ünsüzle biten kelimelerden sonra gelen eklerin yumuşak (tonlu) ünsüzleri, ünsüz uyumu gereği sertleşir. Tonlu ünsüzlerle biten kelimelere getirilen eklerin ilk ünsüzü de ünsüz benzeşmesi gereği değişime uğrayarak tonlulaşır. Ton bakımından ünsüz benzeşmelerinin dışında da ünsüz değişmeleri gerçekleşir. Kutadgu Bilig'den günümüz Kırg1z Türkçesine uzanan zaman dilimi içinde söz konusu ünsüz değişiklikleri ve bunların görüldüğü kelimeler şunlardır:

\section{b $>m$ değişmesi örnekleri}

Örneklerin tamamına yakın kısmında (istisnaları var) b ünsüzü, kelime içindeki nazal (genzel, burunluk) bir sesin etkisiyle $m$ 'ye döner; yani nazallık bakımından benzeşme söz konusudur.

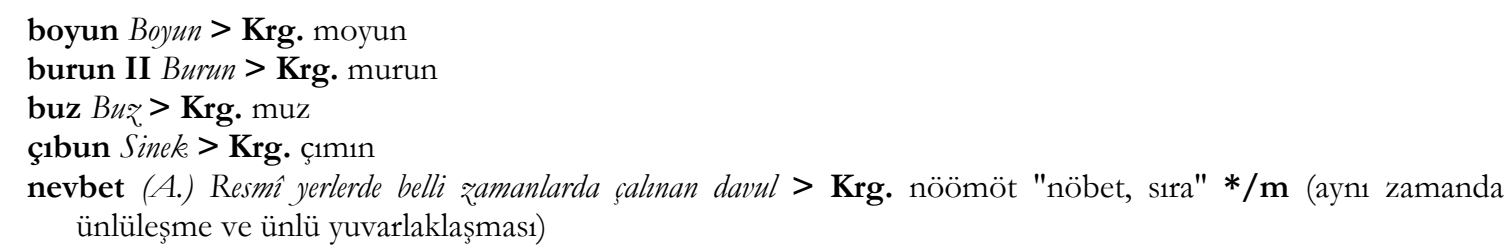

\section{$b>p$ değişmesi örnekleri}

baqır bakır > Krg. cez, mis, pakır (Ton bakımından benzeşme; kelime içindeki k sesinin etkisi var.)

\section{(b) $>w>\ddot{o}$ (ünlü) değişsmesi örnekleri}

tiwe Deve > Krg. töö (Kelimenin Orta Türkçede ve günümüz bazı Türk lehçelerinde hem -b-'li hem -w-li biçimleri mevcut. Bkz. Gülensoy KBS, 2007: 279-280.) (Bu değişim için yukarıda başka örnekler de verilmişti.)

\section{$d>t$ değişmesi örnekleri}

Kelime sonundaki yumuşak ünsüzlerin sertleşmesi, aslında genel kural kabul edilebilir. Örnekleri şunlardır: 
qand (F.) şeker $>$ Krg. kant, kemput, şeker

kend Kent, şehir (Tezcan: Sogutça) > Krg. şaar, kent "kent, şehir"

küḍ- Beklemek > Krg. küt-

\section{$\underline{d}>\boldsymbol{y}$ değgişmesi örnekleri}

Bu ünsüz değişmesi, Türkçenin genel ünsüz değişmelerinden sayılır; pek çok lehçede bunu gözlemleyebiliyoruz. Hatta bu değişmenin dışında kalan Türk lehçelerinin sayısı daha azdır.

Söz konusu değişmenin Kırgız Türkçesindeki örnekleri şunlardır (Bu kısımda d > y değişmesine odaklanılmıştır; örneklerde daha başka ses değişmelerine rastlanabilir):

adaq Ayak > Krg. ayak

aḍ̇ir I Aygir > Krg. aygir

aḍig $A y \imath>$ Krg. ayuu

aḍir- Ayrmak ayır- > Krg. ayır-

aḍ1rt- Ayırtmak, ayırt etmek > Krg. ayır- "ayırmak, ayırt etmek"; actrat- Burada d sesi y’ye döndükten sonra y

sesi de c'ye dönmüss, kelimenin son iki ünsüzü de a ünlüsüyle birbirinden ayrılmıştır.

aḍrıl- Ayrlmak > Krg. bölün-, ayrı-

beḍük Büyük > Krg. biyik "yüksek; büyük, üstün niteliği olan", çoñ, iri, uluu

beḍüklük Büyüklük > Krg. biyiktik"yükseklik; üstünlük" (Aynı zamanda -l- > -t- değişmesi mevcut.)

bod Boy, kamet $>$ Krg. boy, uruu

bodu- Boyamak > Krg. boyo-, sirda-

bodug Boya > Krg. boyok

boḍul- Boyanmak > Krg. boyol- "makyaj yapmak, renklenmek, renkli olmak"

çaḍan Cayan, akerep > Krg. çayan

edgü Iyi > Krg. cakşı, iygi "iyi, güzel, hoş, olumlu; iyilik, güzellik"

eḍgülük İyilik, > Krg. cakşl1ı, iygilik" "başarı" */m

qaḍgu Kaygı > Krg. kayg1, muñ

qadgur- Kaygzlanmak > Krg. kayg1lan-, kayg1r-

qạ̣ın Kayın, kocanın erkek kardeşi > Krg. kayın "kayın, kadın ve kocaya göre birbirinin akrabası", kayın aga, kayın ini

qaḍ̂ñ Kaym ăgacı > Krg. kayıñ

qadit-Dikilmek; geri dönmek > Krg. kayra kel-, kayt-

ked- Giymek > Krg. kiy-

kedim Giyim, giyecek, elbise. bk. kedgü, kedgülük > Krg. kiyim, kiyim-keçek, kostyum

kedür- Giydirmek > Krg. kiydir- */k

qoḍ- Koymak > Krg. koy-; burakmak > Krg. boşot-, kaltır-

quḍruq Kuyruk > Krg. kezek, kuyruk

küḍegü Güveyi > Krg. küyöö "güvey, damat; koca, eş"

muñaḍ- Bunalmak > Krg. demi kıs1l-, sıg1l-, muñay- "üzülmek, üzüntü duymak"

oḍan- Uyanmak. bk. odun- > Krg. oygon- */k; oḍun- uyanmak, bk. odan- > Krg. oygon- */k

oḍgur- Uyandirmak > Krg. oygot- $* / \mathbf{k}$

tod- Doymak > Krg. toy-

udi- Uyumak > Krg. ukta- */e

uḍqu Uyku > Krg. uyku

\section{$(w>) f>p$ değģ̧mesi örnekleri}

Arapça ve Farsçanın sızıcı $f$ sesinin Türk lehçelerinin bir kısmında (Türkmen, Karakalpak, Kazak vd.) patlamalı $p$ sesine dönmesi, genel bir kuraldır. Kırgız Türkçesi de bu kuralın içinde yer alır. Arapça ve Farsçanın p’li kelimeleri, Kutadgu Bilig'de orijinal hâliyle yer alır. Söz konusu değişikliğin örnekleri şunlardır (Kelimelerde özellikle ünlülerle ilgili başka ses olayları da görülür):

fal (A.) Iyi talih, babt > Krg. pal

fariża (A.) Farz > Krg. pariz

felek (A.) Gök, sema > Krg. asman, kam, kök, palek (ağı) */h

ferişte (F.) Melek $>$ Krg. perişte

kafir (A.) Kâfir $>$ Krg. kaapir

qaranfil (A.) Karanfil > Krg. cittuu, kalempir

müsafir (A.) Yolcu > Krg. colooçu, cürgünçü; musapır "zavallı, gariban" */m 
nefs (A.) Nefs > Krg. adamdın özü, kimdik, özdük, napsi

saw (Tezcan: Ar. șāf) Som > Krg. koşundusuz, taza, sap

sefer (A.) Sefer $>$ Krg. sapar

Șifat (A.) S ffat > Krg. kasiyet, sapat, sin atooç; vasıf > Krg. kasiyet, özgöçölük

şifa (A.) Sifa > Krg. ayıguu, şıpa boluu, şıpaa; derman > Krg. al-abal, dan, dan-darmek, darman

feylesuf kelimesi bu kuralın istisnasıdır:

feylesuf (A.) Felsefe ile uğraşan, filozof $>$ Krg. filosof

$\check{g} \sim \dot{g}, g>k$ değişmesi örnekleri

Yumuşak (tonlu) ünsüzlerin sert ünsüzlere dönüşerek tonsuzlaşması, tarihî Türk lehçelerinde de görülür (özellikle Çağatay Türkçesinde). Bu ses olayı, kelimenin başında, ortasında veya sonunda görülebilmektedir. Yeni olmayan bu durumun Kırgız Türkçesindeki örnekleri şunlardır:

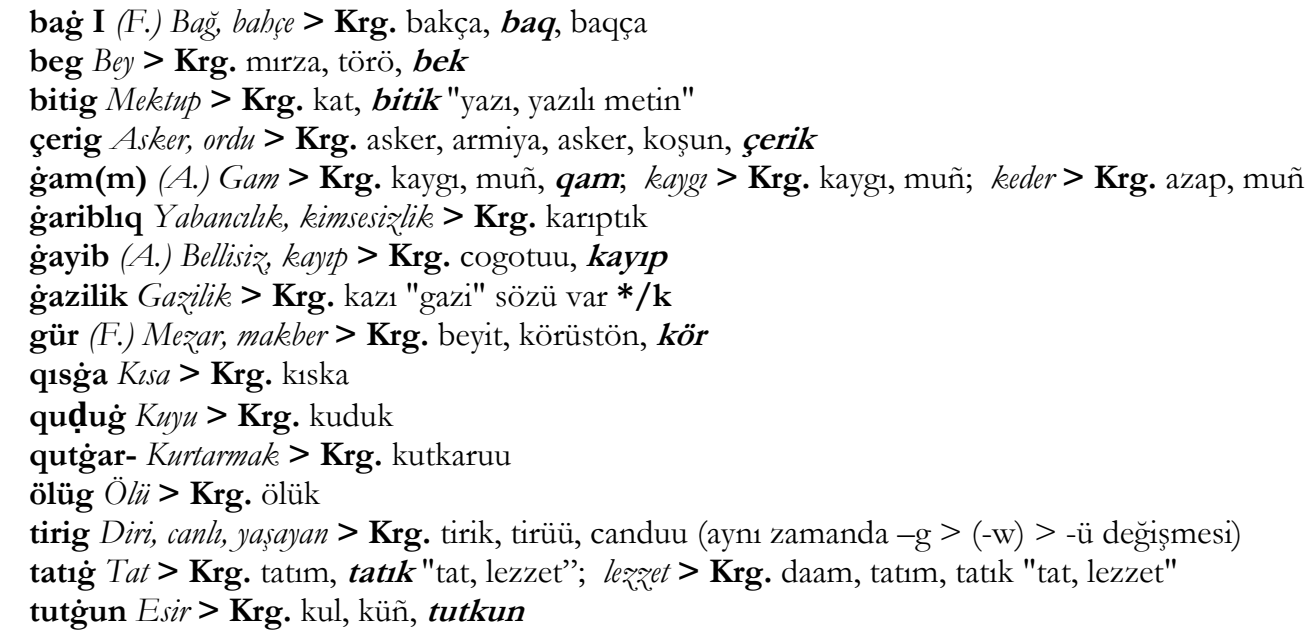

\section{ğ, $g>$ y değişmesi örnekleri}

$\mathrm{Bu}$ değişime, başka Kıpçak grubu Türk lehçelerinde de (örneğin Kazak ve Karakalpak Türkçelerinde) rastlanması, bilinen bir durumdur. Kutadgu Bilig'den hareketle değişimin görüldüğü örnekler şunlardır:

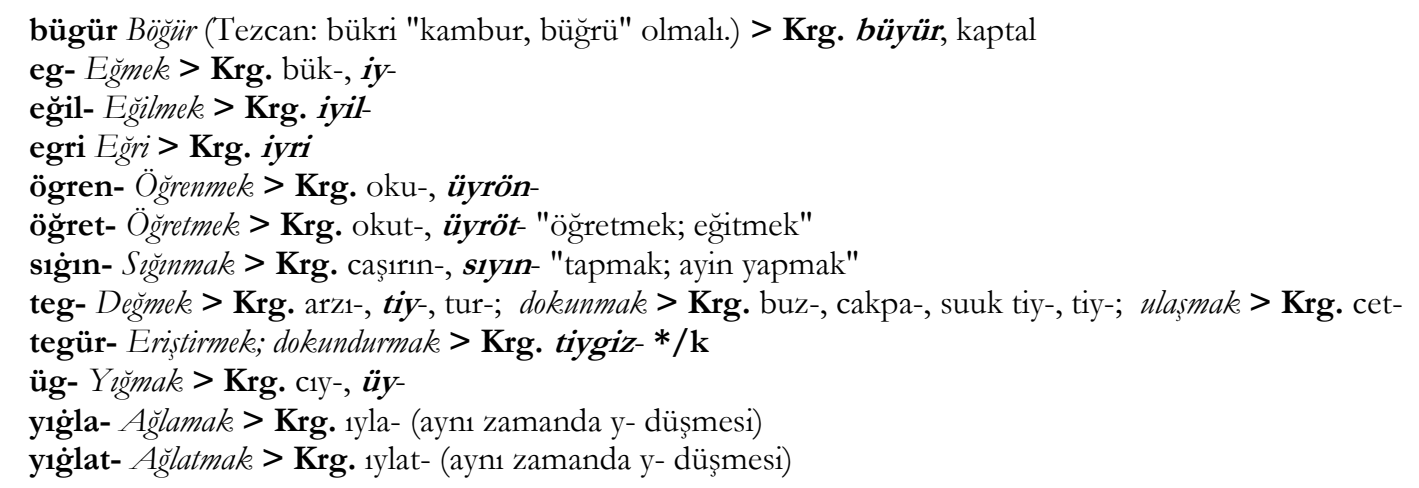

\section{$h>k$ değişmesi örnekleri}

Kırg1z Türkçesinin karakteristik ses değişmelerinden biri de Arapça ve Farsçanın kelime başı, kelime ortası $h$ sesinin ya düşmesi ya da $k$ sesine dönmesidir. Aslında söz konusu değişiklik, sadece Kırg1z Türkçesinde değil, diğer Türk lehçelerinde ve hatta Anadolu ağızlarında da görülür. Aslı k- olan ama sonradan $h$ - sesine değişen bazı Türkçe kelimeler de Kırgı Türkçesinde $k$-llı olabilmektedir. Kutadgu Bilig'de kendisini koruyan bu asli $h$ sesinin Kırg1z Türkçesinde k’ya dönen örnekleri şunlardır:

ahır (A.) Son > Krg. akırkı, akır1, soñku

bahil (A.) Hasis > Krg. cımır, sarañ, bakıl"cimri"

baht (F.) Baht > Krg. bakıt, kut, taalay; talih > Krg. cazmış, tagdır; kısmet > Krg.

haber (A.) Haber > Krg. cañilik, kabar

hacet (A.) İbtiyaç > Krg. kacet, muktacdık; mubtaçlk > Krg. ; qaruret > Krg. macburluk; lüzum, zaruri olan >

Krg. kerektüülük; aræ $и>$ Krg. arzuu, kaaloo, kumardanuu; dilek $>$ Krg. tilek 
halayıq (A.) Yaratılmıs olanlar, mabluklar, halk > Krg. el, curt, kalk, kalayık

halifet (A.) Vekil > Krg. mildet atkaruuçu, kalyypa "halife"

halq (A.) Halk, insanlar, kimseler $>$ Krg. el, curt, kalk

han Han, bükümdar > Krg. ökümdar, kan, xan

harab (A.) Harap olma $>$ Krg. karap

hața (A.) Yanlıs, yanlıs̆lık > Krg. cañılış, kata; kusur > Krg. az ayıp, kusur

hațar (A.) Teblike > Krg. korkunuç, katar"korku, tehlike"

havf $(A$.) Korku > Krg. korkuu, koop

hayr (A.) Iyilik, iyi is > Krg. kayir

hazan (F.) Güz mevsimi, sonbahar > Krg. küz, kazan

hazine (A.) Hazine > Krg. kazina

hitay Hitay, Orta Cin $>$ Krg. Kitay

hiyanet (A.) Hiyanet, hainlik > Krg. çıkkınçılık, kıyanat

hoş (F.) Güzel > Krg. gözöl, cakş1, körktüü, suluu, süykümdüü, $k o s$

Sahabe (A.) Sahabe > Krg. sakaba

taht $(F$.) Tabt $>$ Krg. tak (aynı zamanda sonda $-t$ düşmesi)

\section{h > y değişmesi örnekleri}

Bu ses değişimini barındıran bir örnek tespit edilmiştir:

nașiḥat (A.) Nasihat, ögü̈t > Krg. keñeş, nasıyat

\section{$k>g$ değişmesi örnekleri}

Tonlulaşmanın sebebi, -k- sesinin iki ünlü arasında kalmış olmasıdır:

sekiz Sekiz (8)> Krg. segiz

şükür $(A$. sü̈kr) Sükür > Krg. şügür

tikil- Dikilmek $>$ Krg. tigil-

tökül- Dökülmek > Krg. tögül- "dökülmek, akıtılmak"

\section{$q>\check{g} / \dot{g}$ değişmesi örnekleri}

Söz konusu değişikliğin görüldüğü üç örnekten birinde (taqdir) -q- sesinin yanındaki yumuşak / tonlu -d- sesinin etkisiyle tonlulaşması (ton bakımından benzeşme); diğerlerinde ise $-q$ - sesinin iki ünlü arasında yumuşaması müşahade edilmektedir:

taqdir (A.) Takdir > Krg. caktıruu, kubattoo, tagdir

taq1 $D a$, de, dahi, daha > Krg. da, dag1, dagı da (aynı zamanda t-'nin tonlulaşması t- > d- değişmesi)

toquz Dokuz (9) > Krg. toguz

\section{$k>_{x}$ değgişmesi örnekleri}

kimya (A.) Kimya > Krg. ximiya (Burada Rusçanın etkisi var.)

\section{1> d değişmesi örnekleri}

Bu değişikliğin sebebi, tonluluk bakımından benzeşme kuralıdır. Tonlu ünsüzlerle biten bir kelimeye getirilen ekin ( $+l A$, +lIk) ünsüzü $l$-, $d$-ye döner. Diğer Türk lehçelerinde de görülen söz konusu değişikliğin Kırgız Türkçesindeki (Kutadgu Bilig bağlamında) örnekleri şunlardır:

añla- Anlamak > Krg. añda- (añdoo), tüşün-

azlıq $A$ zlık $>$ Krg. azdik

bütünlük Bütünlïk > Krg. bütündük "bütünlük"

emle- Ilaclamak > Krg. ; tedavi etmek > Krg. darila- (dariloo), emde-; iyileştirmek

erksizlik Kudretsizlik, gücsü̈lïk > Krg. erksiz, erksizdik

erlik Erkeklik > Krg. erdik

esenleş- Esenlik, dilemek, vedalaşmak > Krg. koştoş-, esendeş- "selamlaşmak" */m

esenlik Esenlik, sağlı > Krg. den sooluk, salamattık, esendik"esenlik"

izle- İqlemek, takip etmek > Krg. izde- "aramak, araştırmak", iz kuu "iz sürmek, takip etmek" */k

qulluq Kulluk > Krg. kulduk

künlük Günlük > Krg. kündük

müsülmanlıq Müslümanlık > Krg. musulmandık

tarlıq Darlk $>$ Krg. tardık 
teñle- Denklemek, denkleștirmek > Krg. teñde- "denk duruma getirmek"

tıñla- Dinlemek > Krg. tıñda- (tıñdoo), tıñşa- (tıñşoo), kulak saluu

türlüg Türlü > Krg. ark1l, türdüü

uzluq Ustahk, maharet > Krg. uzduk "ustalık, beceriklilik, maharetlilik", çeberçilik, ustattık

\section{$1>t$ değişmesi örnekleri}

$\mathrm{Bu}$ değişikliğin sebebi, tonsuzluk bakımından benzeşme kuralıdır. Tonsuz ünsüzlerle biten bir kelimeye getirilen ekin $(+l A$, $+l I k)$ ünsüzü $l$-, $t$-ye döner. Kelime kökündeki tonsuz ünsüzün yanındaki $l$ de bazen bu kurala uyar. Diğer Türk lehçelerinde de görülen söz konusu değişikliğin Kırg1z Türkçesindeki (Kutadgu Bilig bağlamında) örnekleri şunlardır:

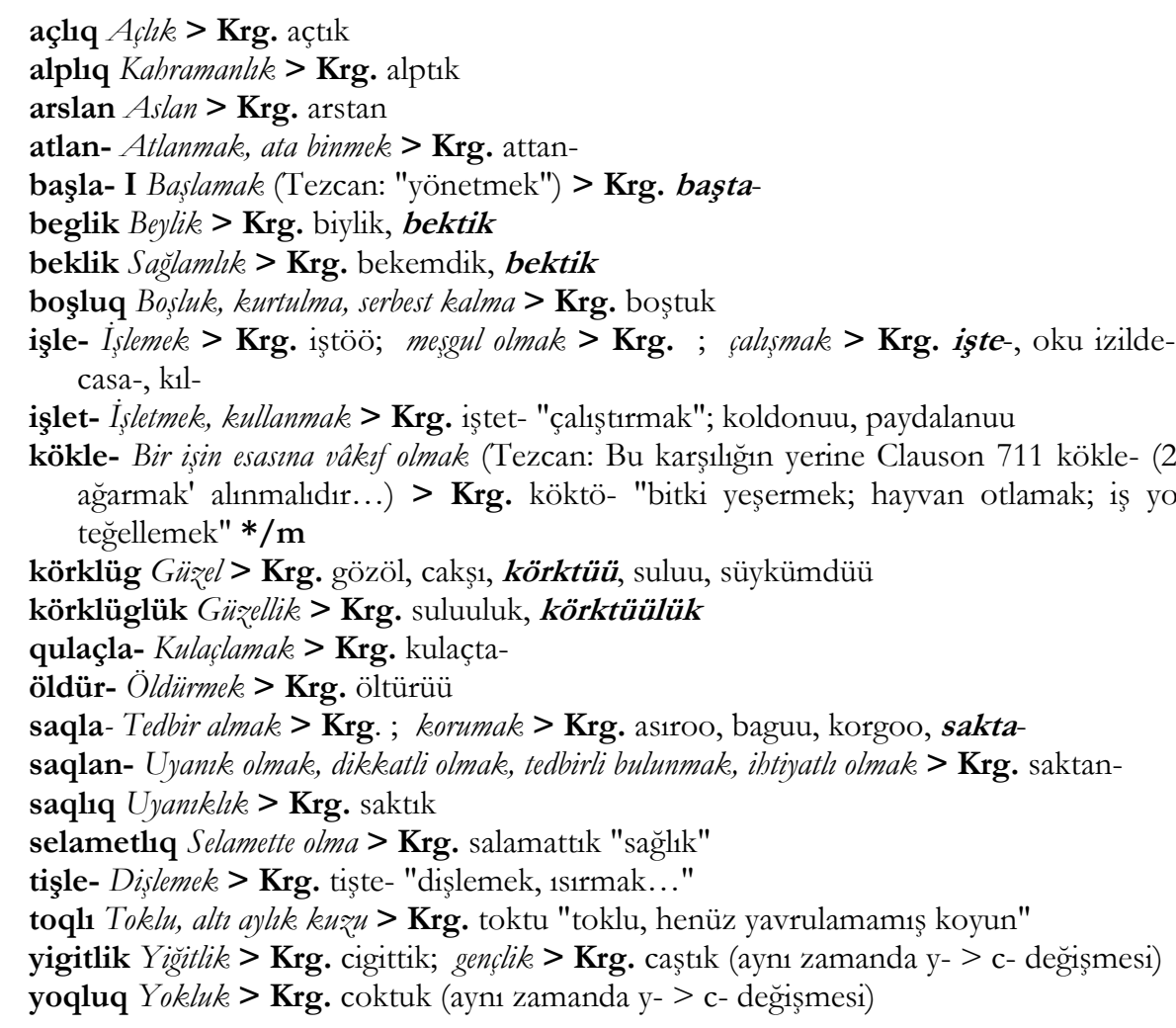

\section{m > n dĕ̈işmesi örnekleri}

Söz konusu değişiklik, bir kelimede tanıklanmıştır. Bunda diş ünsüzü $d$ nin etkisi görülür; yani aslında teşekkül noktası bakımından benzeşme söz konusudur: -md- > -nd-:

emdi Şimdi > Krg. azır, endi, emi

\section{$\tilde{\mathrm{n}}>\mathrm{g}$ değişmesi örnekleri}

$\tilde{n}>g$ değişmesi, yeni bir ses hadisesi olmayıp, Eski Türkçe metinlerde de görülebilen bir değişmedir (Örneğin Köl Tigin Yazıtı Güney yüzü: 6'daki öltüñ yerine öltüg, ölsikiñ yerine ölsikig gibi; Tekin, 1988: 4). Tarihî metinlerde görülebilen bu değişiklik, günümüzde Kırg1z Türkçesinin dişında başka Türk lehçelerinde de görülür. Kutadgu Bilig'deki bir kelime, günümüz Kırg1z Türkçesinde söz konusu değişikliği barındirır:

yalñu Yalnı $>$ Krg. calg1z, calg1z gana; yalñuzluq Yalnı̨llk $>$ Krg. calg1zdık (aynı zamanda $l>d$ değişmesi)

\section{$\tilde{n}>$ m değişmesi örnekleri}

Kutadgu Bilig'deki üç kelimenin günümüz Kırgız Türkçesinde bu değişikliği barındırdığını görmekteyiz:

suñqur Sungur kuşu > Krg. şumkar (aynı zamanda s > ş ve ünlü değişmeleri)

tırñaq Tirnak > Krg. tırmak

üsteñ Üstün, galip > Krg. cogorku, mıktı; ceñüüçü, utuuçu, üstöm "otorite, üstün güç" */k

\section{$\tilde{n}>n$ değişmesi örnekleri}


Söz konusu değişme, Kırgız Türkçesine has değildir, başka Türk lehçelerinde de görülür. Bir örnekte tespit edildi:

$$
\begin{gathered}
\text { yüñ Yün > Krg. cün } \\
p>b \text { değişmesi örnekleri }
\end{gathered}
$$

Tek örnekte, iki ünlü arasında kalan - $p$ - sesinin - $b$ - 'ye döndüğü görülmektedir:

tapın- Tapinmak; bizmette bulunmek > Krg. tabın- "tapmak"

\section{$t>d$ değişmesi örnekleri}

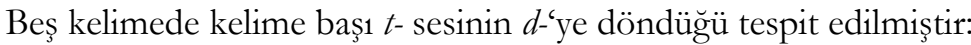

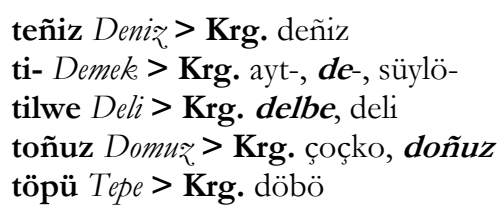

\section{$(b>) w / v>b$ değişmesi örnekleri}

Qawuq ve qawus- kelimeleri, Orta Türkçe metinlerinde (DLT, KB) -w’li kaydedilmiştir ama söz konusu fiillerin aslen - $b$ sesi taşıması gerektiği kaynaklarda belirtilmektedir $(<q \bar{a} b+(u) k$, Gülensoy KBS, $2007: 479$ ve < qabıs- qabus-, Gülensoy KBS, 2007: 481). Kırg1z Türkçesindeki - $b$ - li durumun $w>\mathrm{b}$ değişikliği kapsamında olduğunu kabul ettik. Zira w / v değişmesi, başka kelimelerde de görülmektedir:

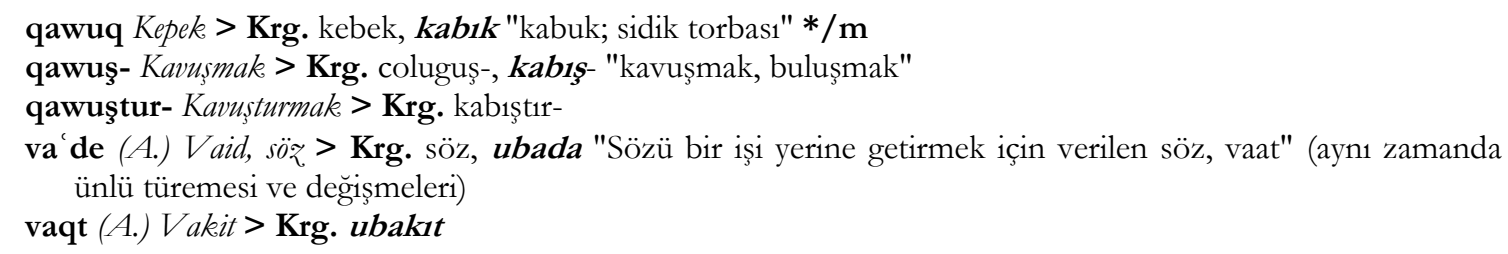

\section{$(b>) w>p$ dĕ̈işmesi örnekleri}

Kutadgu Bilig'deki tek kelimenin Kırg1z Türkçesinde bu değişikliğe maruz kaldığ1 görülmektedir. Bu değişiklik Eski ve Orta Türkçe metinlerinde (ET (Uyg.): övke öpke OT: öpke öwke Gülensoy, KBS, 2007: 649) de günümüz Türk lehçelerinde de görülmektedir (Gülensoy, KBS, 2007: 649): Kelimenin asli şeklini - $p$ - Ii kabul edersek, Kırgız Türkçesi için bir değişiklikten söz etmek olmaz.

öwke Öfke, kıəgınlık > Krg. açuu, öpkö"gücenme, kırgınlık; akciğer" */m

\section{$(b>) w>y$ değişmesi örnekleri}

Eski Türkçede aslen $b$ ünsüzü barındıran bazı kelimeler (eb, ubut), Orta Türkçede, bu bağlamda Kutadgu Bilig'de $w$ olmuştur. Başka Türk lehçelerinde olduğu gibi Kırgız Türkçesinde bunların bir kısmı $y$ ünsüzüne dönüşmüştür. Örnekleri şunlardır:

ew Ev > Krg. üy (< eb Tekin, 1988: 132. Kelimenin Eski Uygur Türkçesinde ew biçimi de mevcuttur, Gülensoy KBS, 2007: 347)

sew-Sevmek > Krg. çaktır-, süy-

sewin- Sevinmek > Krg. süyün- (aynı zamanda ünlü değişmesi)

sewinç Sevinc > Krg. kubanıç, süyünüç

sewindür- Sevindirmek, memnun etmek $>\mathbf{K r g}$. süyündür-

uwut Hayâ > Krg. uyat "utanç, ayıp, ar, hicap; rezalet" (ubut "utanç" Tunyukuk II, Batı: 37; Tekin, 1994: 16)

\section{$y>c$ değişmesi örnekleri}

Bu ses değişmesi, yeni değildir. Tarihî metinlerden, en önemli Kıpçak dil yadigârlarından olan Codex Cumanicus’tan günümüz Kıpçak grubu yazı dillerine (Kazak, Karakalpak, Tatar vd.) kadar geniş bir yelpazede görülür. Yani esasen $y>c(y>j)$ değişmesi, Kıpçak Türkçesinin karakteristik bir özelliğidir. Kutadgu Bilig’den Kırgız Türkçesine ulaşan örnekleri şunlardır:

ya Yay > Krg. caa, saadak, serpilme zim

yad (F.) Anma, hatırlama > Krg. cat "yâd, unutulmaz"

yad.- Yaymak $>$ Krg. cay- (aynı zamanda d > y değişmesi) 
yaḍag Yaya > Krg. cöö (?)

yaḍ1l- Yayılmak > Krg. cayıl- "yayılmak" (aynı zamanda d > y değişmesi)

yag்- Yağmak > Krg. caa-, cıgıluu, cürüü (aynı zamanda ag $>$ oo değişmesi)

yag்1 Düsman > Krg. duşman, $\boldsymbol{c o o}$ (aynı zamanda ag > oo değişmesi)

yaqa Yaka, elbise yakası > Krg. caka, ceek

yaqin Yakin > Krg. cakin, cakında

yaqşı Güz̨el > Krg. gözöl, cakş1, körktüü, suluu, süykümdüü; iy $>$ > Krg. cakş1

yaqut (A.) Yakut $>$ Krg. cakut

yal At yelesi, ense > Krg. celke, cal "Yele"

yalga- Yalamak > Krg. caloo (aynı zamanda g > "ünlüleşme" değssmesi)

yalgan Yalan $>$ Krg. calgan

yalin Alev $>$ Krg. aloo, calin

yalwar- Yalvarmak $>$ Krg. calbar-, suran-

yan Yan, taraf > Krg. cak, can; can-cak

yana Yine $>$ Krg. cana, kaytadan

yanaş- Yanaşmak > Krg. cakında-, canaş-

yañı Yeni > Krg. cañı

yañ1l- Yamimak > Krg. cañil-

yap yaşıl Yemyeşil (Tezcan: Arat'ın çevirisine göre 'mosmor' olmalıdır.) > Krg. capcaşıl

yapuş- Yapışmak > Krg. cabış-

yar- Yarmak > Krg. car-

yara- Yaramak, uygun düsmek > Krg. caraktuu boluu, cara- "uygun, münasip, makbul olmak; yaramak, işine gelmek; yaramak, sağlık bakımından elverişli olmak"

yarag் Imkân; firsat; fayda > Krg. mümkündük; pursat; payda, carak"Araç gereç, alet; silah" */m

yaraşıq Uygun, münasip. bk. yaraşı > Krg. caraktuu, tuura kelgen; llayıktuu, orunduu, caraşık "yaraş1k, yakışı, uygunluk"

yaraştur- Yaraştırmak, uyuşturmak $>$ Krg. caraştır- < caraş-

yarat- Yaratmak, vücuda getirmek $>\mathbf{K r g}$. carat-

yarıl- Yarlmak > Krg. carıl- "yarılmak, bölünmek, patlamak, çatlamak"

yarım Yarm $>$ Krg. carım

yarlı' Buyruk, emir, ferman > Krg. buyruk, carlık, öküm

yas- Dağıtı yaymak, ifrata gitmek > Krg. caz- "yaymak, sermek; açmak; gidermek, dağıtmak, yok etmek"

yasta- Yastık dayamak > Krg. cazda- "yaslamak, dayamak" (ortada ton bakımından benzeşme)

yastan- Yaslanmak > Krg. cazdan- "yaslanmak" (ortada ton bakımından benzeşme)

yaş I Gözyaşı, Yaş > Krg. caş, kurak, suu

yaş II Ömür > Krg. ömür, caş

yaşa- Yaşamak > Krg. caşa-

yaşar- Yeşermek > Krg. bürdö-, kögör-, caşar- "gençleşmek; yenilenmek; yeşermek"

yaşat- Yaşatmak > Krg. caşat-

yaşıl Yeşil (Tezcan: 'yeşil' karşıllı̆̆ yeterli değildir. 23 veride hep 'mavi' anlamındadır.) > Krg. caşıl

yat Yabancı > Krg. çet eldik, cat

yat- Yatmak $>$ Krg. cat-

yay- Yaymak > Krg. cay-

yaz- I Çözmek > Krg. çeçü, çeçüü, caz- "yayma, sermek; açmak"

yazı Kır, ova > Krg. ak-sarı, ay1l, boz, talaa; caz1, tüz, tüzdük

yazıl- Açılmak; çözülmek; Yayılmak > Krg. cazıl- "yayılmak; ayrılmak, çözülmek"

yazuq Suç > Krg. kılmış, künöö; günah > Krg. künö, cazık "Günah, suç"

yel- Koşmak > Krg. çurka-, cügür-, taskakta-, cel- "yelmek, aceleyle telaşlı biçimde koşmak"

yem Yem. bk. yim (Tezcan: yem, yim maddeleri arasında gönderme yapılarak bu sözcükler birirleriyle

karşılaştırılmıştır. Gerçekte Clauson 933 ve devamında belirtildiği üzere bunlar iki ayrı sözcüktür...) > Krg.

cem, cem-çöp

yet- Yetismek, erişmek; kâfi gelmek. > Krg. bış-, bol-; cet-

yetim (A.) Yetim, babası ölmüs kiş̧i > Krg. cetim

yı $\dot{g}-$ I Y Yğmak > Krg. c1y-; toplamak > Krg. çogult-, cıyna-, topta- (aynı zamanda g > y değişmesi)

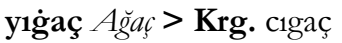

yı̆̆ıl- Toplanmak > Krg. cıyıl- (aynı zamanda g > y değişmesi)

y1q- Yikmak > Krg. c1k-

y1q11- Yikılmak > Krg. cig1-

yil $Y$ ll > Krg. cil

yılan Yilan > Krg. culan

yıldra- Parlamak > Krg. caltır-, carkılda-, carkıra- (aynı zamanda ünlü ve ünsüz değişmesi)

yılq1 Hayvan, hayvan sürüsü > Krg. ayban, c1lkı "yılk1, yılkı atı" 


\section{yılqı̧̧ı Hayvan besleyicisi > Krg. cılkıçı \\ y1par Misk > Krg. muskus, cipar \\ yırt- Yirtmak > Krg. cirt-}

yigit Yiğit > Krg. baatır; genç > Krg. caş, cigit

yilig İlik > Krg. büçü teşigi, çuçuk, cilik, cilik mayı (aynı zamanda -g > -k değişmesi)

yimiş Yemiş, meyve > Krg. cemiş, mömö-cemiş

yiñ Elbise yeni > Krg. ceñ "giysi kolu, yen"

yip $\dot{I} p>$ Krg. arkan, cip

yir Yer > Krg. cer, orun; toprak > Krg. cer, topurak; yeryüzqü > Krg. cer cüzü

yoq Yok > Krg. cok

yoqal- Yok olmak > Krg. cogol- "yok olmak, kaybolmak, yitmek; görünmez olmak" (aynı zamanda ünlü değişmesi ve ünsüzde tonlulaşma)

yoqaru Yukarl > Krg. cogoru (aynı zamanda ünlü değişmesi ve ünsüzde tonlulaşma)

yol Yol > Krg. 1kma, col; sefer > Krg. sapar

yor- II Tabir etmek, yormak. bk. yör- > Krg. cor- "yorumlamak"; yör- çözmek, yormak. bk. yor- > Krg. çeç-; cor$* / \mathbf{v}$

yorıga Yürüyen (Tezcan: Arat'ın çevirisinde olduğu gibi 'rahvan, yorga' alınmalıdır.) > Krg. corgo "Rahvan, yorga; rahvan at" (aynı zamanda ünlü değişmeleri)

yu- Yıkamak > Krg. cuu-

yul- I Kurtarmak; (Tezcan: 'koparmak') > Krg. kutkaruu, cul- "yolmak, çekip koparmak, sökmek; zor kullanarak başkasına ait bir şeyi almak"

yulun- Kurtarmak > Krg. kutkaruu, culun- "çırpınmak; bulunduğu yerden ileri doğru atılmak, firlamak; dizginlenememek, koşmaya çalışmak; sinirlenip dövüşmeye kalkışmak", culkun- */m

yum- Yummak > Krg. cum-

yumdur- Toplamak > Krg. çogult-, cıyna-, topta-, cumdur- "yumdurmak; kapattırmak"

yumşa- Yumuşamak > Krg. cumşa-

yumşaq Yumusak > Krg. cumşak

yumul- Yumulmak > Krg. cumul-

yumuş Hizmet; varife > Krg. kızmat; mildet, cumuş

yun- Yunmak, ynkanmak > Krg. cuun-, cuul- */k

yurt Yurt $>$ Krg. curt, meken; yer $>$ Krg. cer, orun

yügür- Koșmak, seğirtmek > Krg. çurka-, cügür-, taskakta-; bet al-, umtul-

yük $Y \ddot{u ̈ k}>$ Krg. cük

yüz I Ÿ̈z. (100) > Krg. cüz

yüz II Yü̋, çehre > Krg. bet, cüz, üst

\section{$z>y$ değişmesi örnekleri}

Tek örnekteki değişiklik, günümüz Türk lehçelerinin pek çoğunda gerçekleşmiştir.

sözle- Söylemek > Krg. ayt-, süyle-; konuşmak > Krg. añgemeleş-, süyle- (aynı zamanda ünlü değişmesi)

\section{(ayin), ve' (hemze) > b değişmesi örnekleri}

Arapçanın “ayın” gırtlak ünsüzü, Türkçeye yabancı bir sestir. Bu yüzden ya hiç telaffuz edilmez ya da başka bir sese döner. Türk lehçelerinde “ayın” ünsüzünün $\breve{g}, y$, $h$ gibi farklı seslere dönüştügü bilinmektedir. Aşağıdaki iki örnekte ise $b$ sesine dönüşmüştür:

du'a (A.) Allab'a yalvarma, niyaz > Krg. kudayga calbaruu, duba, bata

su'al (A.) Sual > Krg. sobol, suroo (Kelime, su'al > suwal / suval > subal aşamalarından geçmiş olmalıdır. Kelimede aynı zamanda ünlü değişmesi görülmektedir.)

\section{(ayın) > y değişmesi örnekleri}

şeri' at (A.) şeriat > Krg. şariyat

\section{2. Ünsüz Türemeleri}

Kutadgu Bilig'deki bazı kelimelerin Kırgız Türkçesindeki kullanımlarında ünsüz türemelerinin olduğunu görülmektedir. Bunların sayısı az olsa da örnekleri şunlardır:

\section{-g-türemesi}

süñu Süngü > Krg. süñgü (<*sün̈ü+g Gülensoy, KBS 2007: 821; veya *süñ-+-GU (T. Tekin'in görüşü) Gülensoy KBS, 2007: 821. Tekin'in görüşüne göre -g- türemesi yok.) 


\section{-k türemesi}

tü I Tüy > Krg. tük; k.ll > Krg. kıl; saç > Krg. çaç (Aslında hem ET'de hem de OT'de kelimenin tü tük

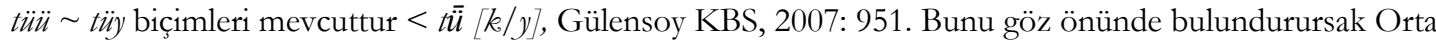
Türkçeden bu yana söz konusu kelimede bir türeme değil, bir varyant biçim düşünülebilir.)

-y- türemesi:

in $\dot{I}_{n}>\mathrm{Krg}$. iyin, uyuk

\section{3. Ünsüz Düşmeleri}

\section{$-d->-0$}

Örneklerde, ortada bulunan sızıcı -ḍ- sesinin (önce -y- veya -g-'ye dönüşmesi sonra da) düşmesi / erimesi söz konusudur:

eḍer Eyer $>$ Krg. eer

ederle- Eyerlemek > Krg. eerde-

idi Sahip > Krg. kocoyun, ee

iḍilik Efendilik > Krg. mırzalıq, tektüülük, eelik"sahiplik, mülkiyet"

$$
g>\varnothing
$$
azdir:

Kelime ortasında veya sonunda bulunan bazı $g / \dot{g}$ seslerinin düştüğü müşahade edilmektedir. Sayıs1

ingek Inek > Krg. inek, uy

kiçig Küçük > Krg. kiçine, kiçi "küçük", kiçinekey; çocukluk > Krg. balalık

qulgaq Kulak, bk. qulaq > Krg. kulak */v

qurug Kuru > Krg. kurgak, kuru; boş > Krg. boş, kuru

qurugisaq Gönül (Tezcan: Tabii burada 'mide, karın' anlamına gelen sözcügün (TTT. kursak) mecazlı kullanımı

söz konusudur...) > Krg. könül, kursak"kursak, karın, mide; iştah" */m

sarı $\dot{g}$ Sar $>$ Krg. sarı

$$
\boldsymbol{h}>\boldsymbol{\varnothing}
$$

Özellikle Arapça ve Farsça kelimelerde bulunan $b$ seslerinin Kırg1z Türkçesinde düştüğü görülür (Düşmeyip $k$ sesine dönüşmeleri $h>k$ değişmesinde gösterilmişti). Örnekleri şunlardır (Örnek kelimelerde başka ses değişiklik / olaylarını da görmek mümkündür):

hac (c) (A.) Hac > Krg. ac1

ḥaq (q) (A.) Hak > Krg. adilettik, ak, akı, akıykattık, Alda, Alla, ukuk; bakikat > Krg. akı1kat, çın, çındık; doğru, > Krg. tuura, tüz; gerçek > Krg. anık, anıktık, çın, çındık

haqiqat (A.) Bir şeyin doğrusu, asıl > Krg. asıl, çınıgı, akıykat, gerçek > Krg. anık, anıktık, çın, çındık

hal (A.) Hâl, durum > Krg. al, al-abal, darman, cabık bazar, cagday, kök bazar, kubat

halal (A.) Helal > Krg. adal, halal

haram (A.) Haram > Krg. aram, haram

harf (A.) Harf > Krg. arip, tamga; yazl > Krg. cazuu, qat "mektup" */m

Hava II (A.) Havva, Adem Peygamberin eşi > Krg. Obo ene /öi

haydar (A.) Haydar, $H_{z}$. Ali $>$ Krg. Aydar

hiç (F.) Hiç > Krg. eç

hịile (A.) Hile $>$ Krg. aldamçılık, kıytırlık, ayla

hindi (F.) Hintli $>$ Krg. Indiyalık $* / \mathbf{k}$

hindu (A.) Hindu $>\mathbf{K r g}$. Indiyalık $* / \mathbf{k}$

hụum (A.) Hüküm > Krg. öküm; emir > Krg. buyruk, carlık, öküm

ḥurmet (A.) Hürmet > Krg. urmat; itibar > Krg. abıroy, bark, kadır, urmat

hüner (F.) Hüner > Krg. çeberlik, önör

miḥnet (A.) Mihnet, sıkıntı > Krg. kıyınç1lık, meenet, kıynaluu, sıgıluu (Ayrıca ünsüz düşmesi sonucu ünlü uzamasi)

padişah (F.) Padişah > Krg. padişa

seher (A.) Seher $>$ Krg. saar, tañ

şehadet (A.) Şehadet, kelime-i şehadet $>$ Krg. şaadat

tesbih (A.) Tesbih > Krg. tespe (aynı zamanda -b- > -p- değişmesi, tonsuzlaşma; ünlü değişmesi/benzeşmesi)

$-1->-\varnothing-$ 
Söz konusu düşme, Türkiye Türkçesi olmak üzere başka Türk lehçelerinde de görülür:

keldür- Getirmek. bk. keltür- > Krg. alıp kel-, ketir-; keltür- Getirmek, bk. keldür- > Krg. alıp kel-, ketir- */v oldur- Oturmak $>$ Krg. otur- (aynı zamanda -d-'den -t-ye tonsuzlaşma)

$-n->-\varnothing-$

Tek örnekte, zamir n'sinin kullanılmadığını görmekteyiz. Bu açıdan bakılırsa herhangi bir ses olayından söz etmek gereksizdir. Bu durum başka Türk lehçelerinde de görülür:

anlar bk. ol > Krg. alar

$-\tilde{\mathbf{n}}->-\varnothing-$

süñuk Kemik > Krg. söök (Kelime, genellikle süyek, süyök aşamalarından geçtikten sonra söök biçimine girer.)

$-r>-\varnothing$

Ek-fiilin ünsüzünün düşmesi, bütün Türk lehçelerinde müşahade edilmektedir.

er- imek, (cevberîfiil) $>$ Krg. e-

$-s->-\varnothing-$

Mescid kelimesinin meçit, meşit biçimlerine dönüşmesi, başka Türk lehçelerinde de görülür.

mescid (A.) Mescit > Krg. kiçine meçit (aynı zamanda -c- > -ç- değişmesi)

$-t>-\varnothing$

Kelime sonundaki çift ünsüzden birinin düşmesi, yadırganacak bir durum değildir ve başka Türk lehçelerinde de pek çok örnekte karşımıza çıkar:

dost (F.) Dost $>$ Krg. dos

$v>\varnothing$

Kelime başı veya ortasında düştüğü gözlemlenmektedir. Kelimedeki düz ünlünün yuvarlaklaşması da söz konusu $v$ sesinin etkisiyledir:

tevbe (A.) Tövbe > Krg. toba (aynı zamanda ünlü yuvarlaklaşması)

vașiyyet (A.) Vasiyet $>\mathbf{K r g}$. osuyat (aynı zamanda ünlü yuvarlaklaşması)

vefa (A.) Vefa > Krg. bektik, berilgendik, opaa "vefa, sadakat" (aynı zamanda ünlü yuvarlaklaşması ve $\mathrm{f}>\mathrm{p}$ değişmesi)

$y->-\varnothing$

Bir kelimede rastladık:

yinçge Ince. bk. yinçke > Krg. içke, cuka; */v; yinçke Ince. bk. yincge > Krg. içke, cuka (ayn1 zamanda $-\mathrm{n}$ - düșmesi)

\subsection{Benzeşme (Asimilasyon) ve Aykırılaşma (Disimilasyon)}

Aşağıdaki örneklerde kelime içindeki ünsüzlerin başka bir ünsüze teşekkül noktası bakımından benzeyerek değiştiğini, bir kısmında ise aykırılaşma (benzeşmezlik) olayının yaşandığına şahit olmaktayız.

q1ymet (A.) Kıymet $>$ Krg. kimbat (k1ymet $>$ kımmat $>$ kımbat), kıybat, nark; değer $>$ Krg. baa, nark

köñlek Gömlek > Krg. köynök (köñlek > köylek > köynök. Aynı zamanda -ñ- > -y-değişmesi)

saç $S_{a c ̧}>$ Krg. çaç

saç- Saçmak > Krg. çaçırat-, çaç-; dağıtmak > Krg.

saç1- Saçlmak, dağzlmak > Krg. tara-, çaçı1-

süçig Tath > Krg. tattuu, tattuu tamak, çuçuk"et sucuğu" */m

Ülker Ülker yıldı̨l > Krg. Ürkör "Ülker takımyıldızı, Süreyya"

nizam (A.) Nizam > Krg. ireet, tartip, miyzam "yasa, kanun, kural" (aynı zamanda -y- türemesi)

minnet (A.) Minnet $>$ Krg. alkış, 1rakmat, mildet kıl- "iyiliği yüze vurmak" (minnet $>$ mindet $\sim$ mildet: Aykirılaşma)

\subsection{Metatez}

Aşağıdaki iki kelimede ünsüz yer değiştirmesi olayını görmekteyiz: 
tepren- Kımıldamak > Krg. araketten-, kıymılda-, termel- < terbel- "sallanmak" (aynı zamanda -b- / -p- > $\mathrm{m}$ - değişmesi, genzelleşme)

yaġmur Yăgmur > Krg. camgır (aynı zamanda y > c değişmesi)

\section{7. Ünlüler ve Ünlü Değişmeleri}

Kutadgu Bilig'deki kelimeler, günümüz Kırgız Türkçesinde ünlü değişmelerine uğrayarak da kullanılmaktadır. Ünlü daralması, ünlü yuvarlaklaşması, ünlü düzleşmesi, ünlü genişlemesi, ünlü türemesi, ünlü düşmesi, ünlü kalınlaşması, ünlü incelmesi gibi ses olaylarının görüldüğü aşağıdaki kelimelerdeki değişmeler, sınıflandırılmaya gerek duyulmadan verilmiştir. Ses değişmelerinden söz ederken kelime telaffuzundaki (veya yazımındaki) tek ölçütün Türkiye Türklerince söylenmekte olan biçiminin esas kabul edilmesinin doğru olmadığı hususunu vurgulamakta yarar vardır. Mesela cemaat $>$ Krg. camaat olmuş, yani ünlü kalınlaşması olmuş demek pek doğru sayılmaz. Zira Kutadgu Bilig yazarı ve onun yaşadığı toplum da bu kelimeyi camaat biçiminde söylemiş olabilir. Biz bu ayırımı kelimenin Arap harfli yazı biçiminden anlayamayız. Aslında bu konunun iki yönü bulunmaktadır. Birincisi, yazım (imla) biçimi, her zaman söyleyiş biçimini yansıtmaz. Çünkü imla, biraz da kalıplaşmaya dayanan yazı biçimidir. Diğer yönü, kelimenin telaffuz biçiminde görülen ünlü veya ünsüz değişmeleri, o kelimenin farklı olduğunu göstermez. $\mathrm{Bu}$, lehçe veya ağız özelliğiyle ilgili bir hususutur. Dolayısıyla "Ünlü Değismeleri” altında topladiğımız aşağıdaki örnekleri, temelde "değişmemiş" kabul etmek mümkündür. Yine de aşağıdaki örnekler, Indeks esas alınarak ünlü değişmelerine dâhil edilmiş örneklerdir:

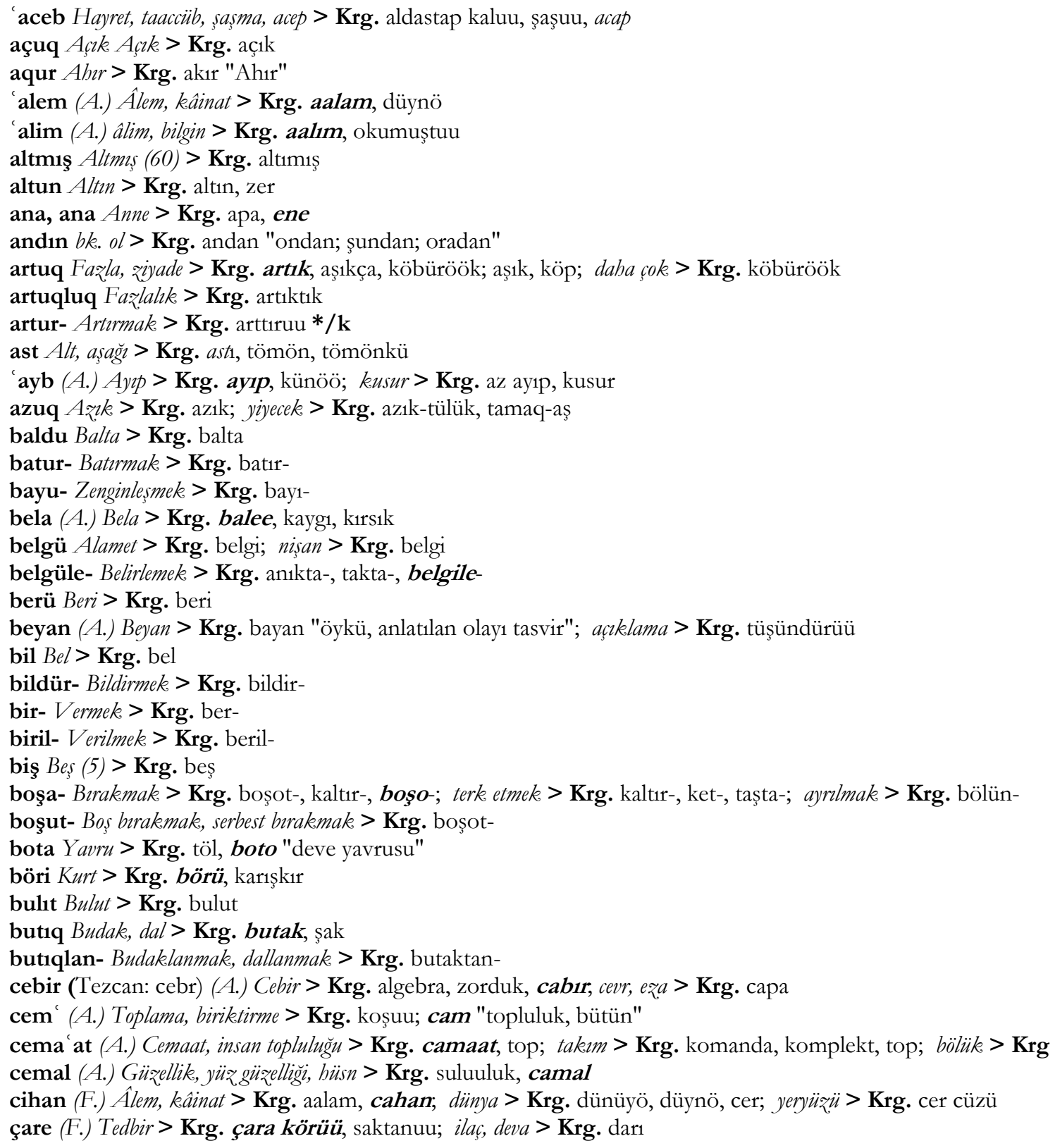


çiçek Ciçek > Krg. çeçek, gül

çim Çim, ayrk otu > Krg. çım

çökür- Cökertmek > Krg. çöktür-, çögör-

dünya (A.) Dünya, âlem > Krg. dünüyö, düynö (aynı zamanda metatez), cer

ecel (A.) Ecel, muayyen vade, ömrün sonu > Krg. acal

edeb (A.) Terbiye, ablak, güzelliği $>$ Krg. adep, tarbiya; hayâ $>$ Krg. uyattuuluk

emanet (A.) Emanet $>$ Krg. amanat

esür- Sarhoș olmak > Krg. esir- "sarhoş olmak; öfkeden kudurmak"

etükçi Ayakekabıcı > Krg. ötükçü

hil 'at (A.) Padişah veya vezir tarafindan takdir edilen kimseye giydirilen elbise > Krg. $\boldsymbol{x a l a t}$ "cübbe, kaftan"

1t $\dot{I}$, k. öpek. bk. it > Krg. it */v

$\mathbf{1 z} \dot{I}_{z}, b k$. iz $>$ Krg. iz */v

içür- İcirmek > Krg. içir-

iki $\dot{I} k i(2)>$ Krg. eki

ikinç İkinci. bk. ikinçi > Krg. ekinçi

il III $\dot{I l}>$ Krg. aymak, çöyrö; memleket > Krg. ölkö, tuulgan cer; ülke > Krg. mamleket, ölkö; halk > Krg. el, curt, kalk

ilahi (A.) Rabbim! Ey Allab’ım, ey Rabbim! > Krg. 1layım (beddua sözlerinde kullanılır) */h

ilçi Elçi $>$ Krg. elçi

ildür- Illistirmek > Krg. ildir- "astırmak"

iman (A.) Iman > Krg. 1man, 1yman, iman; inanmak > Krg. 1nan-, işen-; inanc > Krg. 1nanuu, işenim

imle- İsaret etmek > Krg. belgi berüü, ișaret kıluu, 1mda- "göz kırparak ișaret etmek", 1m sal-

iniş Iniş > Krg. eñis "havza, çukur yer" */m

irin- Ussenmek > Krg. erin-

isi- Isınmak > Krg. c1lınuu; 1s1- "1sınmak; ateșlenmek"

isig Sicak > Krg. 1sık, sicakllk > Krg. temperatura

isin- Isinmak > Krg. c1linuu, 1sin- "1sinmak"

isit- Isitmak > Krg. 1sit-, c1lit-

işaret (A.) $\dot{I}_{\text {şaret }}>\mathbf{K r g}$. ayan, belgi, işarat

işik $K a p_{\imath}>$ Krg. darbaza, eşik, kaalga

işit- Işitmek > Krg. eşit-, uk-; duymak > Krg. eşit-, sez-, tuy-, uk-

it- I Yapmak, etmek, eylemek, kılmak > Krg. casa-, k1l-, et-

'iyal (A.) Bir kimsenin geçindirmek zorunda olduğu kimseler, kadın, eş, çocuk > Krg. ayal, katın; eş > Krg. cubay, siñar, tügöy

qabul (A.) Kabul > Krg. kabıl, kabıldoo

qaçur- Kaçırmak > Krg. kaçır-

qadir (A.) Güclü > Krg. küçtü̈; kudretli > Krg. Kadır "Kadir Tanrı"

qadr (A.) Kadr, değer > Krg. baa, nark, kadir "kadir, değer, kıymet"

kân (F.) Maden > Krg. ken, metall

qanı Hani > Krg. esiñdebi, kana, kayda

qarañqu Karanlık > Krg. karañg1, karañg1lı

keçür- I Geçirmek > Krg. keçir-

keklik Keklik > Krg. kekilik

kenç I Genç > Krg. caş, kence "yaşı küçük..."

kesük Kesik > Krg. kesik

keyik Geyik > Krg. bugu, maral, kiyik"geyik; geyikgiller familyası"

q1ldur- Yaptırmak > Krg. kıldır-

kiç $G$ eç $>$ Krg. keç

kiçe Gece > Krg. tün, keçe "dün" */m

kime Gemi > Krg. keme

kiñe Geniş (Tezcan: Bütün veriler dize sonu ünlemesiyle king e! dir ve hepsi king 'geniş' maddesine aktarılmalıdır.) > Krg. keñ

kiñü- Genişlemek > Krg. keñi- $>$ keñey- $* / \mathbf{e}$

kit- Gitmek > Krg. ket-

kitab (A.) Kitap $>$ Krg. kitep

kiter- Gidermek $>$ Krg. ketir-

qonuq Konuk > Krg. konok, meyman

qorqunç Korkunç > Krg. korkunuç

qorq1t- Korkutmak > Krg. korkut-

qoşn1 Komşu > Krg. koşuna, koñşu

qoşnılıq Komşuluk > Krg. koşunalık 
qoz1 Ku₹u> Krg. kozu

kölike Gölge, bk. kölik > Krg. kölökö; kölik gölge, bk. kölike > Krg. kölökö */v

könek Kova burcu > Krg. könök "kırba, kap, kova" */m

könüldeş Gönül arkadaşı > Krg. könüldöş

köpek Köpek > Krg. it, köpök (eski) */e

köpirt- Köpürtmek > Krg. köbürt-

qudret (A.) Kudret > Krg. kubat, kuduret, küç

qurit- Kurutmak, soldurmak > Krg. kurut- "kurutmak; yok etmek, ortadan kaldırmak"; yok etmek > Krg.

quşçı Kuşcu > Krg. kuşçu "alıcı kuş eğitmeni"

quz1 Kuгu > Krg. kozu

küreş- Güreşmek, boğuşmak > Krg. küröş-

küzet- Gözetmek > Krg. kara-, küzöt- "nöbet tutmak, beklemek, gözetlemek; korumak"; korumak > Krg.

asıra-, bak-, korgo-; saklamak. bk. kü̈lez- $>$ Krg. caşır-, kat-

laçin Şabin kusu > Krg. 1laaçın

ma'lum (A.) Belli > Krg. belgilüü, maalim

mevlud (A.) Mevlit, doğum > Krg. mavlut, mevlüt, tuu, tuuluuş (ayrıca kelime sonunda tonsuzlaşma)

min Ben. bk. men > Krg. kal, men, meñ */v

miraŝ (A.) Miras > Krg. muras

mü'min Mümin > Krg. momun

mürid (A.) Mürit > Krg. murut, şakirt

müsülman (F.) Müslüman > Krg. musulman, musurman

oqçı Okçu, ok atıcısi; ok yapan usta > Krg. okçu

oq1- I okumak > Krg. oku-

oqşa- Benæemek > Krg. okşa-, okşoş-

ol İsaret sö̈ü > Krg. al "o, şu"

onul- İyileşmek > Krg. ayıuu, cakşı boluu, oñol- "düzelmek, iyileşmek"; düzelmek > Krg. oñol-, tüzöl-

ortu Orta, orta halli $>$ Krg. orto

ortuq Ortak > Krg. ortok, şerik

oyna- Oynamak > Krg. kiymılda-, oyna-, şalakta-

ördek Ördek > Krg. ördök

öte- Ödemek > Krg. tölö-, ötö- "yapmak, yerine getirmek" */m

ötel- Ödenmek > Krg. ötöl- "yapılmak" */m

rahmet (A.) Rahmet > Krg. raxmat, 1rakmat "teşekkür, sağol" */m

ruze (F.) Oruc $>$ Krg. orozo

sa' at (A.) Saat $>$ Krg. saat

Sabir (A.) Sabır $>$ Krg. sabır

san- Sanmak > Krg. esepte-, oylo-, sana-; zannetmek > Krg. coromoldo-; düsünmek > Krg. oylon-, oylo-

selam (A.) Selam $>$ Krg. salam

selamet (A.) Selamet $>$ Krg. esen, salamat

semri- Semirmek, yağlanmak, > Krg. semir-

semrit-Semirtmek $>$ Krg. semirt-

sinuq Kirlmıs, kırlk > Krg. kiyragan, singan, sinık

sinür- Sindirmek > Krg. bas-; hąmetmek > Krg. aş k1l-, siñir-

siyaset (A.) Siyaset $>$ Krg. sayasat

soq- Sokmak > Krg. kirgiz-, sal-, tık-, suk- "bıçak vb. şeyler sokmak"; vermek > Krg. ber-

sor- II Sormak > Krg. suro-; aramak > Krg. izde-, kara-, suramcila-, tint-

Șuhbet (A.) Sobbet $>$ Krg. añgemeleşüü, suhbat

sünnet (A.) Sünnet $>$ Krg. sünnöt

şațranc (F.) Satranç > Krg. satıranç, şahmat, şaxmat

țaqat (A.) Güc, kuvvet > Krg. daremet, kıyın, kubat, küç, oor, takaat

taqSir (A.) Kusur > Krg. az ayıp, kusur, taksır"büyüklere saygı sözü; efendim" */m

tamur Damar > Krg. tamır; nabız > Krg. tamırdın kağışı

tamuz- Damlamak (Tezcan: "damlatmak" olarak düzeltilmelidir.) > Krg. tamız- "damlatmak"

tanu- Tanmmak > Krg. bil-, taanı-

taru- Daralmak, dar gelmek > Krg. tar1- "daralmak, darlaşmak, küçülmek; zorlaşmak"

taş $D$ ış $>$ Krg. tış

temür Demir > Krg. temir

temürçi Demirci > Krg. temirçi

teñri Tanr $>$ Krg. kuday, teñir

tertib (A.) Tertip, düzen > Krg. tartip, sistema, tartip, tüzülüş

tılmaç Tercüman > Krg. kotormoçu, tilmeç"tercüman"

tilkü Tilkei $>$ Krg. tülkü 
tir- Dermek, toplamak > Krg. ter-, çogult-, ciyna-, topto-

tirgük Direk > Krg. tirek, türkük, zım karagay (aynı zamanda -g- > -k- değişmesi)

tiz Diz> Krg. tize

toq1ş- Savaşmak, vuruşmak > Krg. soğuş-, togoş- "çarpışmak, savaşmak; birleşmek, karşılaşmak; kesişmek; kavuşmak"

toqit- Dokutmak, yaptrrmak > Krg. tokut-

tolı Dolu > Krg. möndür, tolo

tolu Dolu (Tezcan: "dolunay" alınması gerekir.) > Krg. möndür, tolo

topraq Toprak > Krg. cer, topurak

törtinç Dördüncü. bk. törtünç, törtünçi > Krg. törtünçü

törtünçi Dördüncü. bk. törtinç, törtünçi $>$ Krg. törtünçü

törüt- Yaratmak > Krg. carat-, töröt- "ortaya ç1kmasına sebep olmak; doğurtmak" */m

töşe- Dösemek > Krg. töşö-

töşek Dösek, yatak > Krg. kerebet, körpöçö, say, töşök

töşet- Dössetmek > Krg. töşöt-

tuşıq- Rastlamak > Krg. cologup kal-, kokustan kezdeş-, tuşuk- "karşılaşmak, rastlamak"

țuț (F. țuttî) Papağan > Krg. totu kuş

tüne- Gecelemek $>$ Krg. tünö-

tünek Zindan > Krg. zından, tünök "hayvanların, kuşların gece yattıkları yer, ahır, yuva" */m

Türkçe Türkege $>$ Krg. Türk tili, Türkçö

tüzet- Tanzim etmek, düzeltmek > Krg. tüzöt-

tüzül- Düzelmek > Krg. oñol-, tüzöl-

'ulema (A.) Alimler $>$ Krg. ulama

ul1- Ulumak > Krg. ulu-; inlemek > Krg. kıñkosta-, onto-

ulit- Ulutmak, inletmek > Krg. ulut-

üçünç Ücüncü > Krg. üçünçü

üle- Paylasstrrmak > Krg. böl-, ülö-

ümmet (A.) Ümmet > Krg. ümmöt

ünde-Seslenmek, çağrrmak > Krg. çakıruu, ündö-

üzengü Üzengi > Krg. üzöñgü

vezirlik Veqirlik, > Krg. vazirlik "vezirlik"

yi- Yemek $>$ Krg. ce-

yil II Yel, rüzgâr > Krg. cel, celarg1

yir- Yermek, beğenmemek, hakir görmek > Krg. camanda-, ceri- "kabullenmemek, reddetmek; beğenmemek, nefret etmek" */k

yit- Yitmek > Krg. cogol-, cit- "yitmek, ortadan kaybolmak..."; kaybolmak > Krg. adaș-, cogol-

yiti Yedi (7) > Krg. ceti

yitim Tamam (Tezcan: ... 'eksik' anlamını vermek gerekir. Belki yit-im 'kayba uğramış, eksilmiş' olarak açılkamalıyız...") > Krg. büt, cakșı, carayt, makul, toluk, citim "yitim"

yitür- I Kaybetmek, yitirmek > Krg. cogot-, citir-

yor- I Yürümek. bk. yor- > Krg. cür- (ayn1 zamanda y- > c- değişmesi); yor1- yürümek (Tezcan: S1k s1k 'yaşamak, ömür sürmek, davranmak' anlamlarına geldiği de belirtilmelidir.) $>$ Krg. cür- */v, varmak. bk. yor- > Krg. cet-, kel-

yörgüçi Rüya tabircisi, rüya tabir eden. bk. yorguç > Krg. */v

yulduz Yildrz > Krg. cildız

yüle- Desteklemek. bk. yöle- > Krg. arka boluu, coolook-tayak boluu */v

yürek Yürek > Krg. cürök

zamane (A.) Zamane > Krg. azırkı, bügünkü, zamanası kuurul-/tarı- "çaresiz kalmak" deyimi içinde. */e

zindan (F.) Zindan > Krg. zindan

zinet (A.) Ziynet, süs, bę̧ek > Krg. monçok, z1ynat "sayg1, hürmet gösterme", casalga, azem, şuru-monçok $* / \mathrm{m}$

ziyaret (A.) Ziyaret > Krg. bar-, kel-, z1yarat "ziyaret, kutsal yerleri ziyaret etme"

\section{Sonuç}

Kutadgu Bilig'de, Tezcan'ın dizine eklenmesi gerektiğini söylediği kelimelerle birlikte (18 kelime) toplam 2998 adet kelime bulunmaktadir.

Kutadgu Bilig'de var olup günümüz Türk lehçelerinde manası değğşenlerin sayısı, Krg.T’de 105’tir (\% 3).

Kutadgu Bilig'de var olup günümüz Türk lehçelerinin ağı̨larnda yaşayanlarn sayısı, Krg.T'de 2'dir. Ancak bu veri sağlıklı değildir. Çünkü Kırgız ağız sözlüklerine tam anlamıyla ulaşamadık. 
Kutadgu Bilig'de var olup günümüz Türk lehçelerinde kısmen değģşen yapılarda yaşayanlarn sayısı Krg.T'de 74'tür (\% 2.2).

Kutadgu Bilig'de var olup günümüz Türk lehçelerinde eskiyenlerin sayısı Krg.T’de 21'dir (\% 0.6).

Kutadgu Bilig'de var olup günümüz Türk lehçelerinden sadece Kırgız Türkçesinde olanların sayısı 1544 'tür $(\% 46,2)$.

Bu sayılar ve oranlarda küçük sapmalar olabilir. Zira çok hacimli bir materyal işlenmeye çalışılııştır. Bu yüzden dikkatten kaçanların ve buna bağlı olarak tespitlerde bazı isabetsizliklerin olması mümkündür. Ancak bunların oranı genel sonucu ve kanaati değiştirecek ölçüde olmayacaktır.

Yukarıdaki rakamlar ve oranlar, sadece Kutadgu Bilig'den günümüze ulaşan söz varlığının çağdaş Türk lehçelerinde yaşama oranlarını göstermektedir. Bu, Kutadgu Bilig’in okunduğunda hemen anlaşılacağı manasına gelmez. Çünkü neredeyse pek çok kelime, 11. yüzyıldan 21. yüzyıla gelinceye kadar ses ve hatta anlam bakımından değişmelere uğramıştır. Buna devrin dil bilgisel yapılarını ve unsurlarını da eklemek gerekir. Kafiye, vezin ve daha başka etkenlerle ifadelerin manzum söyleyiş biçimine uyma zorunluluğu da Kutadgu Bilig'in "anlaşılma” derecesi meselesinde göz önünde bulundurulmalıdır.

\section{Etik Beyan}

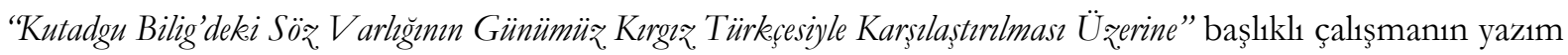
sürecinde bilimsel, etik ve alıntı kurallarına uyulmuş; toplanan veriler üzerinde herhangi bir tahrifat yapılmamış ve bu çalısma herhangi başka bir akademik yayın ortamına değerlendirme için gönderilmemiştir.

\section{Kisaltmalar}

$\begin{array}{ll}\text { A. } & \text { Arapça (İndeks'teki kısaltmaya uyulmuştur.) } \\ \text { DLT } & \text { Divanu Ligati't-Türk } \\ \text { ET } & \text { Eski Türkçe } \\ \text { F. } & \text { Farsça (İndeks'teki kısaltmaya uyulmuştur.) } \\ \text { İFYE } & \text { İsimden Fiil Yapım Eki } \\ \text { KB } & \text { Kutadgu Bilig } \\ \text { KBS } & \text { Köken Bilgisi Sözlüğü } \\ \text { Krg.T. } & \text { Kırg1z Türkçesi } \\ \text { OT } & \text { Orta Türkçe } \\ \text { TT } & \text { Türkiye Türkçesi }\end{array}$

\section{Kaynakça / Bibliography}

Arat, R. R. (1991), Yusuf Has Hacib-Kutadgu Bilig, I-Metin, Ankara: TDK Yay.

Arat, R. R. (1959), Yusuf Has Hacib-Kutadgu Bilig, II-Tercüme, Ankara: TTK Yay.

Arat, R. R. (1979), Kutadgu Bilig III İndeks, (neşre haz. K. Eraslan, O.F. Sertkaya, N. Yüce), İstanbul: TKAE Yay.

Berbercan, M. T. (2013), "Kutadgu Bilig’de Fiillerin Çok Anlamlı Yapısına Genel Bir Bakış", Uluslararası Sosyal Arașttrmalar Dergisi.

Clauson, S. G. (1972). An Etymological Dictionary of Pre-Thirteenth-Century Turkish, Oxford At The Clarendon Press.

Derleme Sözlüğ̈, Ankara: TDK Yay.

Dilâçar, Agop (1995), Kutadgu Bilig Incelemesi, Ankara: TDK Yay.

Doğumunun 990. Yılında Yusuf Has Hacib ve Eseri Kutadgu Bilig Bildirileri (2011), 26-27 Ekim 2009, Ankara: TDK Yay.

Eker, Ö. Ve Kök, A. “Kutadgu Bilig’in Misır Nüshasının Dizini Üzerine Notlar” (2017), Uluslararası Türk Lehçe Arastrumalar Dergisi (TÜRKL AD), Cilt 1, Say1 1: 85-116.

Eker, Ö. Kutadgu Bilig Diæ̨ini (2015), Niğde Üniversitesi, Sosyal Bilimler Enstitüsü. Türk Dili ve Edebiyatı Ana Bilim Dalı, (Danışman: Doç. Dr. Abdullah Kök. Basılmamış Yüksek Lisans Tezi)

Erdal, M. "Kutadgu Bilig Metni” (2009), Doğumunun 990, Yılında Yusuf Has Hacib ve Eseri Kutadgu Bilig Bildirileri, 26-27 Ekim 2009, Ankara: TDK Yay., 2011: 201-208

Gülensoy, T. (2007), Türkiye Türkçesindeki Türkçe Sözcüklerin Köken Bilgisi Sözlüğü, Ankara: TDK Yay.

Gülsevin, G. "Kutadgu Bilig Türkçesinden Anadolu Ağılarına" (2006), Erciyes Üniversitesi Sosyal Bilimler Enstitüsü Dergisi, Say1: 20, Y1l: 2006/1: 109-121.

Gülsevin, G. "Kutadgu Bilig'in Dilinde Lehçelerin Özellikleri: 'Denk Çiftler”" (2007) Turkish Studies / Türkoloji Arastırmalar.

Kaçalin, M. S., Yûsuf Hâs Hâcib, Kutadğu Bilig-Metin (e-kitap), https://docplayer.biz.tr/8272736-Yusuf-has-hacibkutadgu-bilig-metin-hazirlayan-mustafa-s-kacalin.html (erişim tarihi: 27.07.2019). 
UYGUR

Kutadgu Bilig'deki Söz Varlığının Günümüz Kırgız Türkçesiyle Karşılaştırılması Üzerine

Karagöz, İ. "Kutadgu Bilig’in Söz Varlığındaki (Bazı) Hapax Legomenon (Tek Kullanımlık)lar”, Doğumunun 990, Yllnda Yusuf Has Hacib ve Eseri Kutadgu Bilig Bildirileri (2009), 26-27 Ekim 2019, Ankara: TDK Yay., 2011: $267-$ 273.

Karahan, A. "Dîvânu Lugâti't-Türk'e Göre Çiğil Lehçesi ve Karahanlı Yazı Dili ile İlișkisi”" (2009), Uluslararası Türkiyat Araştırmalar Bilgi Şöleni Bildirileri, Kassgarl Mahmut ve Dönemi, Ankara: TDK Yay: 467-477.

Karahan, A. “İlk Türk Lehçeleri Sözlüğü: Dîvânu Lugâti’t-Türk’te Lehçelerin Söz Varlığına Bir Bakış” (2009), Turkish Studies, Volume 4/4 Summer: 650-691.

Karahan, A. Dîvânu Lugâti’t-Türk’e Göre XI. Yüzyıl Türk Lehçe Bilgisi (Doktora Tezi), Ankara Üniversitesi, Sosyal Bilimler Enstitüsü, Ankara 2009.

Karahan, A. "Karahanlı Türkçesi Yazı Dili Hangi Lehçeye Dayanıyordu” (2014), TEKE Dergisi, S. 3/2: 13-28.

Kayasandık, A. (2018), "Türkiye Türkçesinde Ölen Fiiller”, TEKE Dergisi, S. 7/1: 105-125.

Kazak Türkçesi Sözlüğ̈̈ (1984), Tercüme H. Oraltay, N. Yüce, S. Pınar, İstanbul: TDA Vakfi.

Kutadgu Bilig, Kahire Nüshası (1993), Ankara: Kültür Bakanlı̆̆1 Yay.

Kutadgu Bilig, Fergana Nüshası, Ankara: TDK Yay.

Kırgız. Sözdügü (2014), (Haz. Selahattin Çankaya), İstanbul: Bilge Kültür Sanat Yay.

Kirgzz Tilinin Sözdügü (2010), Bişkek: “Avrasya Press”.

Kırgz̨ca-Türkçe Sǫ̈lük (2017), (Haz. E. Arıkoğlu, C. Alimova, R. Askarova, B.Kağan Selçuk), Bişkek: Manas Üniversitesi Yayınları.

Korkmaz, Z. "Kaşgarlı Mahmut ve Oğuz Türkçesi”, Türk Dili, Divanü Lügati’t-Türk Özel Sayısı 253: 3-19.

Mert, A. (2018), "Kutadgu Bilig Nüshalarında Dizine Alınmayan Sözcükler”, Gaz̨i Türkiyat, Güz 2018/23: 221-232.

Ölmez, M. (2004), "Çağdaș Türk Dillerinde Kutadgu Bilig Cevirileri”, Türk Dilleri Araștırmalar.

Önler, Z. (1993), “Kutadgu Bilig'de Ekçek Kelimesi Üzerine”, Türk Dili, S. 497: 342-344

Özbek Tilinin İzabli Lügati (1981), İkki Tomli, Moskva: "Rus Tili" Naşriyati.

Özkan, N. (2009), "Kutadgu Bilig'den Günümüze Türkçe Kelimelerde Anlam Olayları”, Doğumunun 990, Yılında Yusuf Has Hacib ve Eseri Kutadgu Bilig Bildirileri, 26-27 Ekim 2009, Ankara: TDK Yay. 2011: 433-460

Öztürk, F. (2005), “Kutadgu Bilig’de Bitki Adları”, İzmir: Türk Dünyasi Incelemeleri Dergisi.

Salman, H. (2014), "Karluk Devletinin Kuruluş Tarihi Meselesi”, Marmara Türkiyat Arastırmalar Dergisi, C. I, S. I.

Sümer, F. (1994), Eski Türklerde Sehircilik, Ankara.

Tabaklar, Ö. (2009), "Kutadgu Bilig İndeksinde Baz1 Düzeltme Önerileri”, Doğumunun 990, Yılnda Yusuf Has Hacib ve Eseri Kutadgu Bilig Bildirileri, 26-27 Ekim 2009, Ankara: TDK Yay. 2011: 485-492

Taş, İ. (2009), "Kutadgu Bilig'de İndeks’te Yer Almayan İki Sözcük Üzerine”, Doğumunun 990, Yılında Yusuf Has Hacib ve Eseri Kutadgu Bilig Bildirileri, 26-27 Ekim 2009, Ankara: TDK Yay. 2011: 493-504

Tekin, T. (1988), Orhon Yaztllar1, Ankara: TDK Yay.

Tekin, T. (1994), Tunyukuk Yazıt1, Ankara: Simurg Yay.

Tezcan, S. "Kutadgu Bilig Dizini Üzerine" (1981), Ankara: Belleten, C. XLV, S. 178: s. 23-78

Tezcan, S. "Kutadgu Bilig'de Yeni Düzeltmeler" (2009), Doğumunun 990, Yılında Yusuf Has Hacib ve Eseri Kutadgu Bilig Bildirileri, 26-27 Ekim 2009, Ankara: TDK Yay., 2011: 523-534

Yusuf Has Hacib’in Ölümsüz Eseri Kutadgu Bilig (2016), Bişkek: Kırgızistan-Türkiye Manas Üniversitesi Yayınları: 209, Türk Uygarlığı Araştırma Merkezi: 9.

\section{EXTENDED ABSTRACT}

The present study aims to compare the vocabulary of Kutadgu Bilig with the Kyrgyz language of contemporary Turkish dialect, which is the most important and voluminous didactic poem written in Eastern (Karahanids) Turkish of the eleventh century. This study is based on the copies and translations of Kutadgu Bilig published by Reshit Rahmet Arat (Yusuf Has Hajib Kutadgu Bilig I -Metin (Copy), Yusuf Has Hajib Kutadgu Bilig II -Tercume (Translation) and Kutadgu Bilig III which was also prepared by him, but published by K. Eraslan, O. F. Sertkaya, N. Yuje. This study also contains words that are no included in the Index, but recorded by Semih Tezcan as "must be added". The number of this words are 18. This study attempts to compare each word and its meaning from Index with words and meanings in Kyrgyz Turkish; Each descriptive meaning in Kutadgu Bilig is attempted to be given with the closest equivalent into Kyrgyz; change of the meaning, change of the word structures and obsolete words are identified. It can be explained by examples below:

\begin{tabular}{|l|l|l|}
\hline Word & Meaning & Equivalent(s)in Kyrgyz \\
\hline Alp & Giant & Alp \\
\hline & Hero & baatır, kaarman \\
\hline & Brave & kayrattuu, kurç, taymanbas \\
\hline & Valiant & Baatır \\
\hline
\end{tabular}


The number of words with slight change of meaning from Kutadgu Bilig in Kyrgyz is 105 (approxiamtely 3\%). Ther might be a few deviations in this number. Here are some exapmles:

\begin{tabular}{|l|l|l|}
\hline ağru- & Get sick & ooru- "get sick, get worse" \\
\hline alıs- & $\begin{array}{l}\text { Together } \\
\text { ointly } \\
\text { Do } \\
\text { Share }\end{array}$ & alss-"to fight, to struggle; to quarell" \\
\hline alqa- & Applaud & \\
\hline Apa & Mother, human, man & clap, alqa- "make a good wish" \\
\hline
\end{tabular}

Words with slight distortion of structure $(* / \mathrm{k})$. The number of words with slight distortion of structure in Kutadgu Bilig and which exist in Kyrgyz language are 74 (approximately 2.2\%). There might be a few deviations in this number. We can show a few examples below:

\begin{tabular}{|l|l|l|}
\hline aq-1t- & Drain & ag-1z- \\
\hline art-ur- & To Increase & art-tır- \\
\hline aş+ç1 & To cook & aş+ ${ }^{\mathrm{poz}}$, aşpozçu \\
\hline az+la- & To see less, underestimate & az+ + sin- \\
\hline
\end{tabular}

The number of obsolete words from Kutadgu Bilig which reached the Kyrgyz language are 21 $(0.6 \%)$. There may be a few deviations in this number. Examples for obsolete words: $(* / \mathrm{e})$ :

\begin{tabular}{|l|l|l|}
\hline ay- & To say, to speak & ayt-, süyle-. \\
\hline Bayat & Ancients (God) & $\begin{array}{l}\text { bayatadan/bayatdan "lately", bayatadan/bayatdan beri "all } \\
\text { along" }\end{array}$ \\
\hline $\mathbf{1 d}-\mathbf{d i d}$ & Let off & koyo ber- \\
\hline
\end{tabular}

This study also contains words that are "problematic" in terms of reading and intepretation. The number of problematic words mentioned by Tezcan are 103. This study does not include proper nouns. There may be more or less changes in the figures mentioned above.

As a result, approximately 1543 words exist in contemporary Kyrgyz language from Kutadgu Bilig, which contains approximately three thousand (2998) words. This number corresponds to $46 / 47 \%$. We could not mention all 1543 words int this study as we thought that it would increase the lenght of the article, but a large part is insluded. Words that are not included, but recorded by Semih Tezcan as "must be added" in the Index are also available. 